\section{COTTON, TOMATO, CORN, AND ONION PRODUCTION WITH SUBSURFACE DRIP IRRIGATION: A REVIEW}

\author{
F. R. Lamm
}

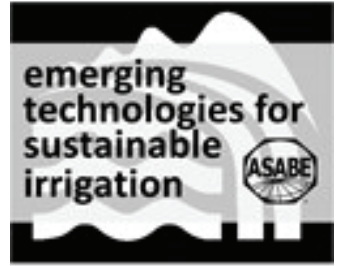

A Tribute to the Career of Terry Howell, Sr.

\begin{abstract}
The usage of subsurface drip irrigation (SDI) has increased by 89\% in the U.S. during the past ten years according to USDA-NASS estimates, and over $93 \%$ of the SDI land area is located in just ten states. Combining public entity and private industry perceptions of SDI in these ten states, the major crops were tentatively identified as cotton, processing tomato, field corn, and onion. An extensive literature review of SDI usage for these four crops was performed concentrating on irrigation system comparisons, water and/or nutrient management, and SDI system design criteria. Although many crops potentially can be grown with SDI, the results presented here may be a relatively representative crosssection of the various opportunities and challenges of SDI for general crop production.
\end{abstract}

Keywords. Crop production, Irrigation methods, Microirrigation, SDI, Trickle irrigation.

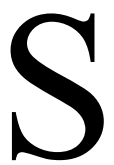

ubsurface drip irrigation (SDI), the application of irrigation below the soil surface by microirrigation emitters (ASAE, 2007) is growing in usage in the U.S. and around the world. In the ten-year period from 2003 to 2013, SDI in the U.S. increased by $89 \%$ from 164,017 to 310,361 ha (fig. 1) according to USDA-NASS irrigation surveys (USDA-NASS, 2004, 2010, 2014). During the same period, SDI averaged approximately $25 \%$ of the surface drip irrigation (DI) land area. (Note: microsprinkler and bubbler irrigation are not included in these estimates). However, this comparison can perhaps be skewed by the fact that some of the reported SDI land area contains shallow, annually removed systems that are not intended for multi-year use. The focus of this review is primarily on deeper systems intended for multi-year use.

SDI has been the subject of three review articles during the past 20 years: Camp (1998) provided an extensive characterization of the knowledge and studies that had been carried out to date, Rodriguez-Sinobas and Gil-Rodriguez (2012) concentrated on design, uniformity, and soil water redistribution aspects, and Devasirvatham (2009) focused on SDI for vegetable production. The status of the technology was also discussed in the 2000 and 2010 national irrigation symposiums sponsored by ASABE and the Irrigation Association (Camp et al., 2000; Lamm et al., 2012). The goal of this review is to augment and supplement those earlier articles with a focus on the important SDI crops currently grown in the U.S.

Submitted for review in February 2015 as manuscript number NRES 11231; approved for publication by the Natural Resources \& Environmental Systems Community of ASABE in March 2015.

Contribution No. 15-304-J from the Kansas Agricultural Experiment Station.

The author is Freddie R. Lamm, ASABE Fellow, Professor, Kansas State University Northwest Research and Extension Center, Colby, KS 67701-0505; phone: 785-462-6281; e-mail: flamm@ksu.edu.
In 2013, the ten U.S. states with the largest SDI area $(289,812$ ha) comprised over $93 \%$ of the total SDI area but had a wide variation in the ratio of SDI/(SDI+DI) land area (fig. 2). The variation can probably be explained by the crop production in these states, with DI often used on higher-value crops (typically fruits, nuts, and vegetables) and SDI used on lesser-value commodity crops (e.g., corn, cotton, alfalfa, and other grain crops). There can be also the persistent perception that SDI is harder to manage, mainly because it provides fewer visual cues when irrigation problems are occurring. As a result, many producers growing the higher-value crops choose DI as a less risky option and because the cost of the irrigation system and its installation are not of paramount concern. When growing the lesservalue commodity crops with microirrigation, a deeper, multi-year SDI system that can be amortized over several years is often the only economical option for a producer. This is particularly true in the Great Plains region, where centerpivot sprinkler irrigation has a good economy of scale and where the major sprinkler manufacturers are located (Nebraska). Although the SDI land area in Nebraska and Kansas (near the center of the Great Plains) is relatively small

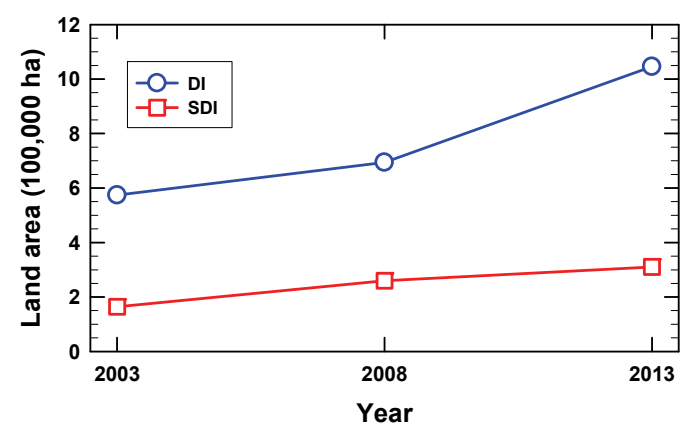

Figure 1. Growth of land area in the U.S. using surface drip irrigation (DI) and subsurface drip irrigation (SDI), 2003 to 2013 according to USDA-NASS surveys (USDA-NASS, 2004, 2010, 2014). 


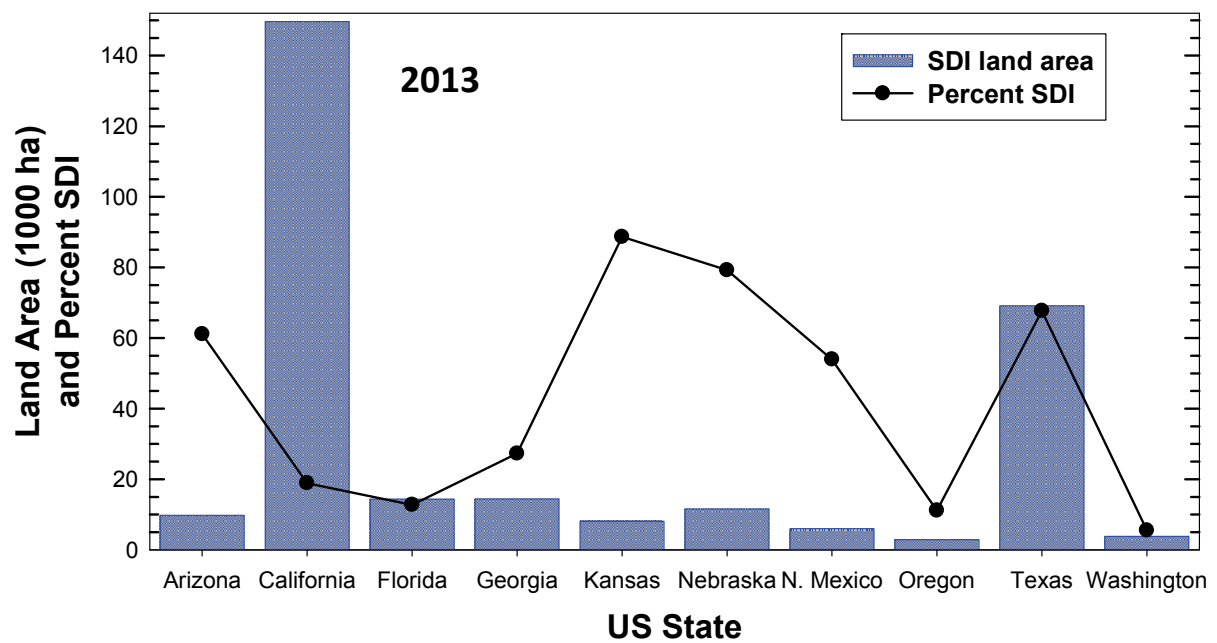

Figure 2. Characteristics of SDI usage in the ten U.S. states having the largest land area devoted to SDI. The percentage of SDI refers to the ratio of SDI to total drip-irrigated land area (total SDI and surface drip irrigation (DI)). Data summarized from USDA-NASS (2014).

(fig. 2), the land area using SDI in these two states has grown by $176 \%$ and $127 \%$, respectively, in the last five years according to USDA-NASS data. The principal irrigated crops in the Great Plains are grain (primarily corn), forage (primarily alfalfa), and fiber crops (i.e., cotton in Texas). However, there can be some exceptions to these overall SDI growth patterns. For example, California has the largest SDI land area in the U.S., and the primary crop using SDI is processing tomato. The growth of SDI in California has been $53 \%$ in the last five years (USDA-NASS, 2010,2014 ), and it is estimated that almost $40 \%$ of the irrigated cropland now uses some type of microirrigation (Taylor et al., 2014).

No national or common state databases exist to link SDI land area with specific crop types, so only opinions from universities, state and federal agencies, and industry personnel could be used to speculate on the crops that use the largest SDI land areas in the U.S. Although there is reasonable consensus that cotton, processing tomato, and field corn constitute the three largest SDI usages, there is much less certainty about onion as the fourth largest usage. Its inclusion in this review was most strongly supported by its reported prevalence in important SDI states in the Pacific Northwest (Oregon and Washington) and its presence in some of the other ten states. Although it is believed that the total SDI land area for vegetables excluding tomato and onion would exceed the SDI onion land area, the totals of individual vegetable crops probably would not. It should also be noted that rotational crops grown on SDI land areas that are primarily for cotton, processing tomato, corn, and onion could add up to a considerable amount for some individual crops, but these crops and land areas are unknown. There are vast geographical, topographical, and climatic differences across the U.S. that affect cropping and irrigation management. This review cannot exhaustively cover all of these aspects. The reader should consult the reported studies for additional details.

\section{CotTon}

Cotton (Gossypium spp.) production is one of the largest usages of SDI in the U.S. and around the world. In suitable climatic regions compatible with cotton production, cotton with its lower water use can be an excellent crop in watershort areas when coupled with efficient SDI. The largest usage of SDI for cotton in the U.S. is in Texas, where 4263 SDI systems covering 107,356 ha primarily for cotton were reported in 2013 for the High Plains Water District alone (HPWD, 2014). It can be noted that this regional value for Texas determined from the physical locations of SDI systems is $55 \%$ greater than the overall Texas area shown in figure 2. This illustrates the difficulty in determining good estimates of SDI land areas in the U.S. The first reported use of SDI for cotton research that was found in this literature review was in 1963 near Lubbock, Texas (Zetzsche and Newman, 1966). In this one-year trial, cotton lint yield was 0.80 and $0.77 \mathrm{Mg} \mathrm{ha}^{-1}$ for SDI and furrow irrigation with irrigation applications of 200 and $355 \mathrm{~mm}$, respectively, in this semi-arid region with summer pattern precipitation. Since that time, cotton has been the focus crop of many research studies and reports. Major SDI cotton research topics have been comparisons of production under SDI and alternative systems; responses to SDI for a particular region, soil, or climate; water and nutrient management; and SDI system design criteria.

\section{System Comparisons for Cotton}

Sixteen studies were found in the literature that allowed equal or nearly equal comparisons of cotton lint yield under SDI and alternative irrigation systems (table 1). Lint yield increases when using SDI as compared to alternative systems ranged from $-1 \%$ to $+65 \%$, with an average increase of $18 \%$ across all studies. Subsurface drip irrigated cotton lint yields were $2 \%, 15 \%$, and $19 \%$ greater than DI, surface gravity, and sprinkler irrigation, respectively, in these studies. Greater incidence of spider mites with SDI as compared to sprinkler irrigation was reported in a study in California (Hollingsworth et al., 2014) and was attributed to drier and dustier leaves with the SDI system. In that same study, although yield differences were slightly greater for the sprinkler system and weed plant densities were similar, there was much greater weed biomass under the sprinkler. 
Table 1. Cotton lint yield $\left(\mathrm{Mg} \mathrm{ha}^{-1}\right)$ as affected by irrigation method and average lint yield increase attributable to SDI.

\begin{tabular}{|c|c|c|c|c|c|c|c|c|c|c|c|}
\hline $\begin{array}{l}\text { Research } \\
\text { Report }\end{array}$ & $\begin{array}{c}\text { Additional Factors } \\
\text { or Comments }\end{array}$ & $\begin{array}{l}\text { Soil } \\
\text { Type }\end{array}$ & $\begin{array}{l}\text { SDI } \\
\text { Dripline } \\
\text { Depth } \\
(\mathrm{m}) \\
\end{array}$ & $\begin{array}{l}\text { Subsurface } \\
\text { Drip } \\
\text { (SDI) } \\
\end{array}$ & $\begin{array}{l}\text { Surface } \\
\text { Drip } \\
\text { (DI) }\end{array}$ & $\begin{array}{l}\text { Surface } \\
\text { Gravity }\end{array}$ & $\begin{array}{c}\text { Other } \\
\text { Sprinkler }\end{array}$ & $\begin{array}{c}\text { MESA } \\
\text { Sprinkler }\end{array}$ & $\begin{array}{c}\text { LESA } \\
\text { Sprinkler }\end{array}$ & $\begin{array}{c}\text { LEPA } \\
\text { Sprinkler } \\
\end{array}$ & $\begin{array}{l}\text { Average Increased } \\
\text { Yield using SDI } \\
\text { over Alternative } \\
\text { Methods (\%) } \\
\end{array}$ \\
\hline Ayars et al., 1999 & All years & $\begin{array}{l}\text { Silty } \\
\text { clay }\end{array}$ & $\begin{array}{c}0.4 \text { and } \\
0.6\end{array}$ & 1.73 & - & 1.47 & - & - & - & - & 18 \\
\hline \multirow{6}{*}{$\begin{array}{l}\text { Bordovsky and } \\
\text { Lyle, } 1998\end{array}$} & $2.5 \mathrm{~mm} \mathrm{~d}^{-1}$ capacity & \multirow{6}{*}{ Loam } & \multirow{6}{*}{0.3} & 1.28 & - & - & - & - & - & 1.05 & 22 \\
\hline & $5.1 \mathrm{~mm} \mathrm{~d}^{-1}$ capacity & & & 1.37 & - & - & - & - & - & 1.26 & 9 \\
\hline & $7.6 \mathrm{~mm} \mathrm{~d}^{-1}$ capacity & & & 1.41 & - & - & - & - & - & 1.31 & 8 \\
\hline & 1 d LEPA frequency & & & 1.36 & - & - & - & - & - & 1.20 & 13 \\
\hline & 2 d LEPA frequency & & & 1.36 & - & - & - & - & - & 1.21 & 12 \\
\hline & 3 d LEPA frequency & & & 1.36 & - & - & - & - & - & 1.20 & 13 \\
\hline \multirow{4}{*}{$\begin{array}{l}\text { Bordovsky and } \\
\text { Porter, } 2003\end{array}$} & $\begin{array}{c}\text { Limited pre-season } \\
\text { irrigation } \\
\end{array}$ & \multirow{4}{*}{ Loam } & \multirow{4}{*}{0.3} & 1.14 & - & - & - & - & 0.83 & 0.95 & 28 \\
\hline & $\begin{array}{l}\text { Full pre-season } \\
\text { irrigation }\end{array}$ & & & 1.18 & - & - & - & - & 0.95 & 1.05 & 18 \\
\hline & $2.5 \mathrm{~mm} \mathrm{~d}^{-1}$ capacity & & & 1.01 & - & - & - & - & 0.71 & 0.85 & 29 \\
\hline & $5.1 \mathrm{~mm} \mathrm{~d}^{-1}$ capacity & & & 1.31 & - & - & - & - & 1.07 & 1.14 & 18 \\
\hline Bhattarai et al., 2005 & SDI data for $75 \% \mathrm{ET}$ & Clay & 0.4 & 1.93 & - & 2.15 & - & - & - & - & -10 \\
\hline \multirow{4}{*}{ Colaizzi et al., 2010} & $25 \%$ of full irrigation & \multirow{4}{*}{$\begin{array}{l}\text { Clay } \\
\text { loam }\end{array}$} & \multirow{4}{*}{0.3} & 0.64 & - & - & - & 0.46 & 0.49 & 0.55 & 28 \\
\hline & $50 \%$ of full irrigation & & & 0.80 & - & - & - & 0.56 & 0.56 & 0.74 & 29 \\
\hline & $75 \%$ of full irrigation & & & 1.02 & - & - & - & 0.78 & 0.75 & 0.87 & 28 \\
\hline & $100 \%$ of full irrigation & & & 1.07 & - & - & - & 0.87 & 0.89 & 0.99 & 16 \\
\hline $\begin{array}{c}\text { Constable and } \\
\text { Hodgson, } 1990\end{array}$ & All varieties & Clay & 0.2 & 1.81 & 1.77 & 1.76 & - & - & - & - & 3 \\
\hline Grabow et al., 2002 & - & $\begin{array}{l}\text { Clay } \\
\text { loam }\end{array}$ & $\begin{array}{l}0.3 \text { and } \\
0.45\end{array}$ & 1.42 & - & - & 1.21 & - & - & - & 17 \\
\hline \multirow{2}{*}{ Hanson et al., 1970} & Heavy irrigation & \multirow{2}{*}{$\begin{array}{c}\text { Not } \\
\text { listed }\end{array}$} & \multirow{2}{*}{0.3} & 1.62 & - & 1.41 & - & - & - & - & 15 \\
\hline & Light irrigation & & & 1.53 & - & 1.44 & - & - & - & - & 6 \\
\hline $\begin{array}{l}\text { Hollingsworth et al., } \\
\qquad 2014\end{array}$ & - & $\begin{array}{l}\text { Clay } \\
\text { loam }\end{array}$ & 0.3 & 1.46 & - & - & 1.48 & - & - & - & -1 \\
\hline Nuti et al., 2006 & - & $\begin{array}{l}\text { Sandy } \\
\text { loam }\end{array}$ & 0.25 & 1.47 & - & - & 1.40 & - & - & - & 5 \\
\hline \multirow{2}{*}{ Phene et al., 1992} & Good soil & \multirow{2}{*}{$\begin{array}{c}\text { Sandy } \\
\text { loam }\end{array}$} & \multirow{2}{*}{0.375} & 1.87 & - & 1.89 & - & - & - & - & -1 \\
\hline & Poor soil & & & 1.78 & - & 1.56 & - & - & - & - & 14 \\
\hline Smith et al., 1991 & - & $\begin{array}{c}\text { Fine } \\
\text { textured }\end{array}$ & 0.45 & 1.71 & - & 1.20 & - & - & - & 1.14 & 46 \\
\hline Sorensen et al., 2004 & $\begin{array}{l}2000 \text { data for } \\
\text { full irrigation }\end{array}$ & $\begin{array}{c}\text { Sandy } \\
\text { loam }\end{array}$ & $\begin{array}{c}0.30 \text { to } \\
0.35 \\
\end{array}$ & 1.26 & - & - & 1.26 & - & - & - & 0 \\
\hline $\begin{array}{l}\text { Thompson and } \\
\text { Enciso, } 2002\end{array}$ & Commercial farm data & NA & NA & 1.05 & - & 0.71 & - & - & - & - & 48 \\
\hline \multirow{2}{*}{ Tollefson, 1985} & SDI and furrow & \multirow{2}{*}{ NA } & \multirow{2}{*}{$\begin{array}{c}0.20 \text { to } \\
0.25\end{array}$} & 2.12 & - & 1.60 & - & - & - & - & 33 \\
\hline & SDI and sprinkler & & & 2.23 & - & - & 1.35 & - & - & - & 65 \\
\hline \multirow[t]{5}{*}{$\begin{array}{l}\text { Whitaker et al., } \\
2008 \\
\end{array}$} & Data for two locations & $\begin{array}{l}\text { Loamy } \\
\text { sand }\end{array}$ & 0.25 & 1.41 & - & 1.32 & - & - & - & - & 6 \\
\hline & & & \multicolumn{8}{|c|}{ Average SDI increase across all studies and treatments: } & 18 \\
\hline & & & \multicolumn{8}{|c|}{ Average SDI increase over surface gravity irrigation across all studies: } & 15 \\
\hline & & & \multirow{2}{*}{\multicolumn{8}{|c|}{$\begin{array}{r}\text { Average SDI increase over all sprinkler irrigation treatments across all studies: } \\
\text { Average SDI increase over DI across all studies: }\end{array}$}} & 19 \\
\hline & & & & & & & & & & & 2 \\
\hline
\end{tabular}

The most extensive SDI to sprinkler irrigation comparisons have been conducted in Texas (Bordovsky and Lyle, 1998; Colaizzi et al., 2010). In these studies, SDI had $12 \%$ to $28 \%$ greater cotton lint yields when compared to three types of sprinkler application, i.e., low-elevation spray application (LESA), mid-elevation spray application (MESA), and low-energy precision application (LEPA), which are all considered efficient sprinkler application methods for this region.

In these sixteen studies, the SDI lint yield advantage tended to be greatest when irrigation was limited and tended to decrease as irrigation levels increased and became more sufficient. This latter statement is generally consistent with results presented elsewhere for grain, fiber, and forage crops (Camp, 1998; Lamm et al., 2010). Possible reasons are that when water is sufficient, the irrigation method matters less in overall yield, while at greater irrigation levels there is increased possibility of nutrient leaching or soil aeration problems. Generally, the SDI increases in cotton lint yields as compared to alternative systems were greater on finer-textured soils than on coarse-textured soils (table 1). There can be notable exceptions to this conclusion, such as when lateral or upward soil water redistribution on heavier clay soils is negatively affected, resulting in stand establishment or crop water stress later in the season. Soil water redistribution and aeration have been the topics of concern for cotton production on clay soils in several SDI studies from Australia (Constable and Hodgson, 1990; Hulme and O'Brien 2000; Bhattarai et al., 2004, 2005). On sandier soils, greater leaching may occur under SDI when irrigated with practices similar to other irrigation systems or when the sandy soil may not retain a large enough wetted volume for the seed establishment zone and crop root zone. However, $13 \%$ greater SDI lint yields as compared to furrow irrigation were reported on a non-uniform sandy loam soil with buried pockets of sand scattered throughout 
the field (Phene et al., 1992). The usage of SDI may have resulted in more consistent and uniform soil water within the crop root zone for this non-uniform soil, even though the furrow-irrigated treatment received $82 \%$ more irrigation.

Crop water productivity was almost always greater with SDI in these sixteen system comparison studies, particularly in the studies in which SDI was compared to surface gravity irrigation methods. These overall results might be partially attributed to greater partitioning of total water use to transpiration with SDI, less deep percolation, no irrigation runoff, and less evaporative loss (possibly both soil water evaporative loss and irrigation application loss). There is also growing evidence (Colaizzi et al., 2010) that SDI, by not wetting the soil surface, provides a more favorable thermal environment (warmer) and more heat units for irrigated cotton, which is important, particularly as cotton production moves farther northward in the Texas Panhandle, Oklahoma, and southern Kansas.

\section{Conjunctive Nutrient and Water Management \\ for Cotton}

Greater SDI cotton lint yield was obtained with an intermediate level of irrigation than with full irrigation on a sandy loam soil in Georgia (Sorensen et al., 2004), which might be attributable to nitrogen $(\mathrm{N})$ leaching. The authors concluded that combined irrigation and $\mathrm{N}$ management with SDI might lead to decreased $\mathrm{N}$ requirements as compared to typical regional fertilization practices. A similar conclusion was stated for SDI cotton on a loamy sand soil for a four-year study in South Carolina that compared $\mathrm{N}$ application under every row and alternate row middle dripline spacings (Bauer et al., 1997; Camp et al., 1997). The potential for $\mathrm{N}$ savings was similarly reported for field corn grown with SDI on a deep silt loam soil in Kansas (Lamm et al., 2001, 2004). Timing of $\mathrm{N}$ applications for cotton can affect yields, and Constable et al. (1990) concluded that all $\mathrm{N}$ should be applied by mid-flowering of cotton and that perhaps as much as $30 \%$ of the total $\mathrm{N}$ should be applied before planting on a cracking clay soil in Australia. Excellent N and phosphorus (P) uptake through SDI fertigation was reported for cotton, resulting in greater $\mathrm{N}$ and $\mathrm{P}$ amounts in the leaf analyses in a study in Australia, but this did not result in greater yields (Aloni et al., 2000). The authors indicated that the yield results might have been confounded by differences in treatment water applications and dripline spacings. Extractable P concentrations in the immediate vicinity of a subsurface point source were $20 \%$ to $25 \%$ greater with continuous $\mathrm{P}$ fertigation than with periodic applications (Ben-Gal and Dudley, 2003), resulting in 20\% greater biomass for sweet corn plants at 40 days post-emergence.

\section{SDI Frequency for Cotton}

Frequent microirrigation events are often considered a necessary and desirable practice, but an SDI literature review (Camp, 1998) indicated that SDI frequency is typically only critical for shallow-rooted crops on shallow or sandy soils or in cases where salinity is a major concern. In a deficit-irrigated cotton study on a silty clay loam in Texas, frequency of SDI under deficit irrigation was not an important factor (Enciso-Medina et al., 2003). There were no differences in cotton yield, quality, or gross returns related to SDI frequency, and the authors concluded that longer periods (as much as 16 days) between irrigation may allow irrigators to use less expensive, manually operated SDI systems. Irrigation frequencies of four events per day, every two days, and weekly were compared for two irrigation levels (approx. 40\% and 80\% of ET) for cotton on a clay loam soil in Texas (Bordovsky et al., 2012a). When averaged over the three years of the study, there were no statistical differences in yield for the drier irrigation treatment attributable to irrigation frequency, and the every two day and weekly frequencies were superior for the wetter irrigation treatment. A study in Israel on a heavy clay soil reported similar cotton seed yields for irrigation frequencies of two or five times weekly (Plaut et al., 1985). These studies indicate that high frequency is not required for cotton production. Cotton often benefits from some plant water stress in the process of setting bolls and establishing overall plant size, and it is possible that irrigation frequency is less important because of this.

\section{Dripline Depth for Cotton}

Installation depth for SDI cotton has been a research topic in several studies (Kamara et al., 1991; Plaut et al., 1996; Khalilian et al., 2000; Enciso et al., 2005). Cotton production was evaluated for dripline depths of $0.20,0.31$, and $0.41 \mathrm{~m}$ on a loamy sand with a clay hardpan at the 0.25 to $0.32 \mathrm{~m}$ depth in South Carolina (Khalilian et al., 2000). The authors found that plant height was significantly greater for the $0.41 \mathrm{~m}$ depth and that the $0.20 \mathrm{~m}$ depth had greater weed infestations, which required additional application of herbicides. Lint yields were greater with increased dripline depth in both years of the study, averaging 1.29, 1.38 , and $1.47 \mathrm{Mg} \mathrm{ha}^{-1}$ for depths of $0.20,0.31$, and $0.41 \mathrm{~m}$, respectively. In a study in semi-arid Lubbock, Texas, on a fine sandy loam soil, cotton root development and distribution were not affected by dripline depths of $0,0.15,0.30$, and $0.45 \mathrm{~m}$ (Kamara et al., 1991), suggesting that dripline depth will not be the overriding factor in root development and distribution in regions that typically receive precipitation during the active growing season. In a laboratory column study on a loessial brown loam using SDI, Plaut et al. (1996) found that cotton roots could develop under partial wetting of the upper soil profile to soil water potentials of $0.1 \mathrm{MPa}$. They suggested that a reasonable dripline depth for cotton would be 0.4 to $0.5 \mathrm{~m}$. Lint yields were $5 \%$ greater for a $0.3 \mathrm{~m}$ dripline depth as compared to a $0.2 \mathrm{~m}$ depth on a clay loam site in western Texas (Enciso et al., 2005). In the sixteen studies listed in table 1 , the average depth was $0.32 \mathrm{~m}$. In summarizing these overall results, deeper dripline depth $(0.30 \mathrm{~m}$ or greater $)$ tends to be advantageous for cotton, provided that germination and crop establishment are not a concern.

\section{Dripline Spacing for Cotton}

Dripline spacing for cotton has been the focus of SDI research studies in Georgia (Sorensen et al., 2011), South Carolina (Bauer et al., 1997; Camp et al., 1997; Khalilian et al., 2000), and Texas (Enciso-Medina et al., 2005). In the humid region (South Carolina), a dripline spacing of $2 \mathrm{~m}$ 
for cotton using an alternate row/bed middle pattern (i.e., one dripline centered between two rows) was usually adequate and more economical, saving about $30 \%$ in SDI system costs compared to a $1 \mathrm{~m}$ dripline spacing (Bauer et al., 1997; Camp et al., 1997). Averaging eight years of lint yield data from SDI on a sandy loam in Georgia, Sorensen et al. (2011) concluded that an alternate row furrow lateral spacing was as effective as driplines placed under every crop row. Similarly, no differences in cotton lint yield were reported for every row versus alternate row middle dripline placements on a loamy sand in another study in South Carolina (Khalilian et al., 2000). The wider alternate row middle spacings might present greater problems for germination and crop establishment during drought periods on coarser-textured soils, as suggested by Camp et al. (1997). Similarly, a decreased SDI wetting pattern can occur on hardsetting soils with poor soil structure. It was concluded that a wider $2 \mathrm{~m}$ dripline spacing, commonly used for cotton in Australia, was not appropriate on hardsetting red soils due to the limited flow perpendicular to the dripline (Hulme and O'Brien, 2000). In a three-year study in semiarid Texas, overall cotton lint yields were $21 \%$ greater for a $1 \mathrm{~m}$ dripline spacing placed under every crop row than for an alternate row middle dripline spacing of $2 \mathrm{~m}$ (Enciso et al., 2005). In that study, yields were severely reduced with the wider spacing in one year due to seed germination failure. However, in another year, the wider spacing outperformed the narrower dripline spacing, leading the authors to conclude that further research was needed on dripline placement and its interaction with wheel traffic and tillage/bed management. Climate, soil, and crop rooting characteristics can affect the required dripline spacing and placement. When germination and crop establishment are of less concern, there is general agreement that the alternate row/bed dripline spacing (about $1.5 \mathrm{~m}$ ) is adequate for most deeper-rooted agronomic crops, such as cotton on medium to heavy textured soils (Camp, 1998).

\section{Summary of SDI for Cotton}

Cotton lint yield increases averaging 19\% as compared to sprinkler irrigation, as listed here, illustrate why SDI is increasingly being adopted in Texas. The yield increases tended to be greatest for SDI when irrigation was limited. Conjunctive management of nutrients and irrigation should help further SDI adoption for cotton. Frequency of SDI has not been a major issue, and this has allowed some producers to use less costly, manually operated systems. Dripline depths of approximately $0.30 \mathrm{~m}$ allow for normal cultural practices and allow for long-term, multi-year SDI systems. Dripline spacings are most often an alternate row middle arrangement, which helps keep SDI system costs down. Cotton is a major commodity crop in the U.S., but it does not produce the net returns that are possible with highervalue fruits and vegetables. Therefore, reliable, multi-year, cost-effective SDI systems are important for cotton.

\section{Tomato}

Tomato (Solanum lycopersicum L.) production is one of the largest usages of SDI in the U.S., primarily in California for processing tomato. Estimates from University of
California-Davis (Montazar, 2015) indicate that SDI has become the commercial standard for processing tomato, with over 100,000 ha or approximately $80 \%$ of the processing tomato land area. This would suggest that $60 \%$ to $65 \%$ of the SDI land area in California is used for processing tomato. The advantages of using SDI for processing tomato was thoroughly discussed by Phene et al. (1987). Much of this early work by Phene et al. (1987) and follow-up research was summarized by Ayars et al. (1999). Tomato has been the focus crop of many other research studies and reports. Major SDI tomato research topics have been comparisons of production under SDI and alternative systems; responses to SDI for a particular region, soil, or climate; water and nutrient management; and SDI system design criteria.

\section{System Comparisons for Tomato}

A total of sixteen studies were found in the literature that allowed equal or nearly equal comparisons of tomato yield under SDI and alternative irrigation systems (table 2). SDI yield increases ranged from $-32 \%$ to $+205 \%$, with an average positive increase of $12 \%$ across all studies. Subsurface drip irrigated tomato yields were $7 \%, 17 \%$, and $23 \%$ greater than DI, surface gravity, and sprinkler irrigation, respectively, in these studies. Large yield reductions $(31 \%$ to $32 \%$ ) with SDI were reported in three studies for which the authors suggested possible rationale. A yield reduction $(32 \%)$ with SDI was reported on a fine sand in Florida, and it was suggested that yield reductions were the result of water availability rather than nutrient management (Clark et al., 1993). The shallow root zone of tomato was insufficient to efficiently use irrigation water applied by driplines at a $0.3 \mathrm{~m}$ depth. In a study in California on a clay loam soil examining the effects of SDI on weed control, a yield reduction of $32 \%$ was attributed to early cutoff of irrigation for the SDI treatment (Shrestha et al., 2007). Although SDI yields were severely affected by irrigation management, the authors reported that weed emergence was nearly eliminated in the furrows and the amount of weeds on the crop bed was reduced from $46 \%$ to $96 \%$. Similar reports of reduced weed growth with SDI as compared to sprinkler irrigation were reported by Grattan et al. (1990) for processing tomato. Greater processing tomato yield with DI than SDI was attributed to serious root intrusion that occurred mid-season in SDI for a study in Canada (Tan et al., 2003). It was suggested that water stress that likely occurred before the SDI system was replaced with surface drip for the remainder of the season caused the $31 \%$ yield reduction. In contrast, more than half of the studies had tomato yield increases of $10 \%$ or greater for the most productive treatments (table 2).

\section{Conjunctive Nutrient and Water Management for Tomato}

The studies conducted by the USDA Water Management Research Laboratory in California (Ayars et al., 1999) are worth noting in that they illustrate how combined irrigation and nutrient management can be beneficial to tomato production with SDI. Tomato yields were $10 \%$ greater on a clay loam soil when $P$ and potassium $(K)$ were injected with high-frequency SDI compared to low-frequency DI, without a concurrent increase in crop water use, thus result- 
Table 2. Tomato yield $\left(\mathrm{Mg} \mathrm{ha}^{-1}\right)$ as affected by irrigation method and average yield increase attributable to SDI.

\begin{tabular}{|c|c|c|c|c|c|c|c|c|c|}
\hline $\begin{array}{l}\text { Research } \\
\text { Report }\end{array}$ & $\begin{array}{c}\text { Substudy } \\
\text { or Comments }\end{array}$ & $\begin{array}{l}\text { Additional } \\
\text { Factors }\end{array}$ & $\begin{array}{l}\text { Soil } \\
\text { Type }\end{array}$ & $\begin{array}{l}\text { SDI } \\
\text { Dripline } \\
\text { Depth } \\
(\mathrm{m}) \\
\end{array}$ & $\begin{array}{l}\text { Subsurface } \\
\text { Drip } \\
\text { (SDI) } \\
\end{array}$ & $\begin{array}{l}\text { Surface } \\
\text { Drip } \\
\text { (DI) }\end{array}$ & $\begin{array}{l}\text { Surface } \\
\text { Gravity }\end{array}$ & Sprinkler & $\begin{array}{l}\text { Average Increased } \\
\text { Yield using SDI } \\
\text { over Alternative } \\
\text { Methods }(\%) \\
\end{array}$ \\
\hline \multirow{10}{*}{ Ayars et al., 1999} & CSUF study, 1981 & - & Sandy loam & 0.46 & 132 & - & 90 & - & 47 \\
\hline & \multirow{3}{*}{$\begin{array}{l}\text { Westside Field Station } \\
\text { study, 1984-1987; high- } \\
\text { frequency SDI and DI }\end{array}$} & $\mathrm{N}$ only, 1984 & \multirow{3}{*}{$\begin{array}{l}\text { Clay } \\
\text { loam }\end{array}$} & \multirow{3}{*}{0.45} & 121 & 126 & - & - & -4 \\
\hline & & $\mathrm{N}+\mathrm{P}, 1985$ & & & 168 & 152 & - & - & 11 \\
\hline & & $\mathrm{N}+\mathrm{P}+\mathrm{K}, 1987$ & & & 220 & 201 & - & - & 9 \\
\hline & \multirow{3}{*}{$\begin{array}{l}\text { Westside Field Station } \\
\text { study, 1987; high- } \\
\text { frequency SDI and DI; } \\
\text { continuous P injection }\end{array}$} & No P & \multirow{3}{*}{$\begin{array}{l}\text { Clay } \\
\text { loam }\end{array}$} & \multirow{3}{*}{0.45} & 184 & 177 & - & - & 4 \\
\hline & & $\mathrm{P}, 67 \mathrm{~kg} \mathrm{ha}^{-1}$ & & & 220 & 201 & - & - & 9 \\
\hline & & $\mathrm{P}, 134 \mathrm{~kg} \mathrm{ha}^{-1}$ & & & 215 & 192 & - & - & 12 \\
\hline & \multirow{3}{*}{$\begin{array}{l}\text { Westside Field Station } \\
\text { study, 1987; high- } \\
\text { frequency SDI and DI }\end{array}$} & N only, 1990 & \multirow{3}{*}{$\begin{array}{l}\text { Clay } \\
\text { loam }\end{array}$} & \multirow{3}{*}{0.45} & 143 & 143 & - & - & 0 \\
\hline & & $\mathrm{N}+\mathrm{P}, 1990$ & & & 182 & 155 & - & - & 17 \\
\hline & & $\mathrm{N}+\mathrm{P}+\mathrm{K}, 1990$ & & & 179 & 154 & - & - & 16 \\
\hline Batchelor et al., 1994 & Small garden study & $\begin{array}{c}\text { Average of six } \\
\text { irrigation treatments }\end{array}$ & $\begin{array}{l}\text { Sandy clay } \\
\text { loam }\end{array}$ & 0.15 & 96 & - & 96 & - & 0 \\
\hline \multirow{3}{*}{ Bogle et al., 1989} & \multirow{3}{*}{ Fresh market tomato } & Spring 1983 & \multirow{3}{*}{$\begin{array}{l}\text { Sandy clay } \\
\text { loam }\end{array}$} & \multirow{3}{*}{$\begin{array}{l}0.15 \\
\text { to } 0.20\end{array}$} & 39 & - & 32 & - & 22 \\
\hline & & Fall 1983 & & & 34 & - & 28 & - & 21 \\
\hline & & Spring 1984 & & & 52 & - & 43 & - & 21 \\
\hline Clark et al., 1993 & Fresh market tomato & Spring 1993 & Fine sand & 0.30 & 54 & 79 & - & - & -32 \\
\hline \multirow{2}{*}{$\begin{array}{c}\text { del Amor and } \\
\text { del Amor, } 2007 \\
\end{array}$} & \multirow{2}{*}{ Two irrigation levels } & $50 \%$ irrigation & \multirow{2}{*}{$\begin{array}{l}\text { Clay } \\
\text { loam }\end{array}$} & \multirow{2}{*}{0.40} & 58 & 19 & - & - & 205 \\
\hline & & $100 \%$ irrigation & & & 76 & 70 & - & - & 9 \\
\hline \multirow{4}{*}{$\begin{array}{l}\text { El-Gindy and } \\
\text { El-Araby, } 1996\end{array}$} & \multirow{4}{*}{$\begin{array}{c}\text { Varying irrigation } \\
\text { frequency and emitter } \\
\text { discharge on high- } \\
\text { salinity soil }\end{array}$} & Daily, high flow & \multirow{4}{*}{$\begin{array}{l}\text { Loamy } \\
\text { mixed }\end{array}$} & \multirow{4}{*}{$\begin{array}{l}0.25 \\
\text { to } 0.30\end{array}$} & 45 & 35 & - & - & 29 \\
\hline & & Daily, low flow & & & 33 & 33 & - & - & 0 \\
\hline & & 3 day, high flow & & & 30 & 34 & - & - & -12 \\
\hline & & 3 day, low flow & & & 28 & 31 & - & - & -10 \\
\hline & Weed study for & No herbicide & & & 119 & - & 78 & 78 & 53 \\
\hline Grattan et al., 1990 & $\begin{array}{l}\text { processing tomato, } \\
\text { reds shown here. }\end{array}$ & Herbicide & NA & 0.25 & 117 & - & 101 & 105 & 14 \\
\hline Hanson and Mav 2000 & Processing tomato & Year 1999 data & Silty clay & 0.20 & 104 & - & - & 82 & 27 \\
\hline Hanson and vay, 2000 & Processing tomato & for two sites & Clay loam & to 0.23 & 91 & - & - & 79 & 15 \\
\hline Hanson and May, 2003a & Processing tomato & 2000 data & NA & 0.20 & 86 & - & - & 64 & 34 \\
\hline Hanson and May, 2007 & Processing tomato & 2004-2006 data & NA & 0.23 & 114 & 96 & & & 18 \\
\hline Machado et al 2003 & Average of 1997-1998 & $0.2 \mathrm{~m}$ depth SDI & Sand & See trt. & 130 & 115 & - & - & 13 \\
\hline Macnado et al., 2003 & & $0.4 \mathrm{~m}$ depth SDI & Sand & depth & 128 & 115 & - & - & 11 \\
\hline Machado et al 2005 & Averaged across & $0.2 \mathrm{~m}$ depth SDI & Sand & See trt. & 118 & 119 & - & - & -1 \\
\hline Mracnado et al., 2005 & three irrigation levels & $0.4 \mathrm{~m}$ depth SDI & sand & depth & 107 & 119 & - & - & -10 \\
\hline Marouelli and Silva 2002 & & $0.2 \mathrm{~m}$ depth SDI & Clay & See trt. & 116 & 124 & & 108 & 0 \\
\hline Marouelli and Silva, 2002 & & $0.4 \mathrm{~m}$ depth SDI & Clay & depth & 94 & 124 & & 108 & -28 \\
\hline Najafi and Tabatabaei, & & $0.15 \mathrm{~m}$ depth SDI & Silty & See trt. & 52 & 53 & 44 & & 8 \\
\hline 2007 & & $0.30 \mathrm{~m}$ depth SDI & loam & depth & 37 & 53 & 44 & & -23 \\
\hline Shrestha et al., 2007 & $\begin{array}{l}\text { Conventional vs. } \\
\text { conservation tillage }\end{array}$ & 2004-2005 data & $\begin{array}{l}\text { Clay } \\
\text { loam }\end{array}$ & 0.23 & 64 & - & 94 & - & -32 \\
\hline & Study on two soil types. & $\begin{array}{l}\text { Broadcast } \\
\text { fertilization }\end{array}$ & Loamy & NA & 139 & 130 & - & - & 7 \\
\hline Ton et al 2003 & SDI failed due to root & Fertigated & & & 139 & 133 & - & - & 5 \\
\hline ran el al., 2003 & with DI in season for & $\begin{array}{c}\text { Broadcast } \\
\text { fertilization }\end{array}$ & Clay & NA & 97 & 114 & - & - & -15 \\
\hline & & Fertigated & & & 84 & 121 & - & - & -31 \\
\hline & & & & Averag & e SDI increas & across al & tudies an & treatments: & 12 \\
\hline & & & Average SL & I increase & over surface & ravity irrig & tion acros & all studies: & 17 \\
\hline & & Aver & ge SDI increa & se over all & sprinkler irrig & ation treat & ents acros & all studies: & 23 \\
\hline & & & & & Average SDI & ncrease ov & r DI acros & all studies: & 7 \\
\hline
\end{tabular}

ing in $13 \%$ greater crop water productivity for the highfrequency SDI (Phene et al., 1990). Rooting and nutrient uptake patterns were deeper with SDI and $\mathrm{P}$ fertigation; similarly, petiole $\mathrm{P}$ deficiencies were observed when $\mathrm{P}$ was not injected (Ayars et al., 1999). Tomato yields were 35\% greater with daily SDI than with events every third day on a calcareous soil in Egypt (El-Gindy and El-Araby, 1996). The more frequent irrigation events resulted in wider wetting patterns and may have reduced salinity in the vicinity of the roots. However, Hanson et al. (2003) reported no yield benefit with SDI $(0.2 \mathrm{~m}$ depth) for multiple irrigation events per day for processing tomato compared with frequencies as low as weekly on a silt loam soil in California. The P fertilizer in that study was applied preplant, and the
$\mathrm{N}$ was applied weekly. These studies show that irrigation frequency can interact with soil characteristics and nutrient management practices in different ways.

\section{Dripline Depth for Tomato}

Various dripline depths have been compared in a few studies for SDI tomato production (Schwankl et al., 1990; Machado et al., 2003, 2005). Seed germination of directseeded processing tomato at a seeding depth of $0.038 \mathrm{~m}$ averaged $219 \%$ better at dripline depths of 0.15 and $0.23 \mathrm{~m}$ than at $0.30 \mathrm{~m}$ (Schwankl et al., 1990) when averaged over three seedling irrigation rates on a Yolo clay loam soil in California. The authors concluded that acceptable tomato stands could be achieved with SDI as the sole source of 
irrigation for germination. In some areas, sprinkler irrigation is used for tomato crop establishment, so using SDI for this purpose would be less of a concern. No significant differences were reported for dripline depths of 0.2 and $0.4 \mathrm{~m}$ for tomato production on sand for two studies in Portugal (Machado et al., 2003, 2005), although they did report conflicting results for SDI and DI comparisons (table 1). In the sixteen studies (table 2), the average depth was $0.27 \mathrm{~m}$, with a dripline depth range of 0.15 to $0.25 \mathrm{~m}$ being most common. There has been increased use of transplants for processing tomato in California, and the transplanting process would probably not rely solely on SDI for crop establishment.

\section{Salinity Management for Tomato}

Soil and water source salinity can be a constraint in tomato production, and SDI can potentially help manage salinity. Little correlation was found for processing tomato yield and soil salinity level for SDI in a study in California (Hanson and May, 2003a). The authors concluded that soil salinity with SDI may affect tomato yield less than with other irrigation methods. This could be because SDI provides a more consistent soil water environment than alternative systems. Tomato yields in that study were 12.9 to $22.6 \mathrm{Mg} \mathrm{ha}^{-1}$ greater with SDI than with sprinkler irrigation for similar irrigation amounts. Sodium and chloride accumulations were reduced in tomato plant tissues with SDI compared to DI on a silty clay soil in Tunisia, resulting in greater leaf area and chlorophyll for the SDI tomato plants (Kahlaoui et al., 2011). Less salt accumulation was present in the active root zone, and denser root systems formed with SDI than with DI for tomato on a calcareous soil in Egypt (El-Gindy and El-Araby, 1996). This was attributed to better soil water redistribution within the root zone. Greater horizontal movement of the water occurred with larger $4 \mathrm{~L} \mathrm{~h}^{-1}$ emitters, compared with greater downward movement for $2 \mathrm{~L} \mathrm{~h}^{-1}$ emitters. However, there was still an expressed concern that SDI may cause excessive salt accumulation in the seed and transplant zone for the next crop. The management of crop location with respect to dripline location can be important for even moderately saline water with SDI systems that are used for multiple years, unless periodic leaching is provided. Root activity was limited to the wetted soil volume for drip-irrigated tomato on a sandy soil, but the rooting patterns were different for fresh and saline water (Ben-Asher and Silberbush, 1992). When freshwater was used, a relatively high root density occurred around the periphery of the wetted volume, but with saline water limited root activity existed at the periphery. In summarizing the studies listed here, it appears that with precise management SDI can be appreciably better than other irrigation systems for use with saline water for tomato production.

\section{Summary of SDI for Tomato}

Yield increases averaging $12 \%$ as compared to alternative irrigation systems, as listed here, illustrate why SDI has become the commercial standard for processing tomato with large SDI land areas in California. Combined nutrient and water management, which is easily attainable with SDI, results in sizable yield increases. A dripline depth range of
0.15 to $0.35 \mathrm{~m}$ is common. Salinity management for tomato production in arid regions can be enhanced with SDI, but care must be taken to avoid salinity hotspots within the crop beds.

\section{CORN}

Field corn (Zea mays L.) is the largest irrigated crop in the U.S., with typically 4.85 to 5.40 million ha harvested for grain in recent years (USDA-NASS, 2014); therefore, even though the land area using SDI for corn is much smaller than for cotton and tomato production, it is still an important usage and has been the topic of many research studies. Although the SDI land area for corn could not be determined, university and government agency anecdotal responses to inquiries by this author in early 2015 reported some SDI corn production (grain and/or forage) in six (Florida, Georgia, Kansas, Nebraska, Oregon, and Texas) of the top ten states having the largest SDI land area in the U.S. (USDA-NASS, 2014). The earliest reported usage of SDI for corn in the U.S. was in 1915-1916 on a deep silt loam soil at the West College Farm of Colorado State University (House, 1918). The description of the irrigation system is somewhat similar to a subirrigation system, but the system was not used for controlling the height of the water table. In that early study, porous clay tiles were installed at a depth of $0.6 \mathrm{~m}$ on various lateral spacings of 4.9 to $7.6 \mathrm{~m}$. Precipitation in 1915 at the location was greater than normal, so corn yield measurements were not recorded. Dry conditions in 1916 resulted in large plant height differences, ranging from approximately 1 to $2 \mathrm{~m}$ across the width of the widely spaced subsurface laterals. The author concluded that the technology would not be cost-effective for ordinary farm crops such as corn, that narrower lateral spacings would be needed for grain crops on that soil type, and that a smaller water supply that would be infeasible for a surface gravity system could be sufficient for a subsurface system. In a three-year study (1965-1967) near Georgetown, Delaware, Mitchell et al. (1969) reported some early SDI corn research evaluating flexible plastic tubing with various orifices and dripline spacings (1, 1.5, and $2 \mathrm{~m}$ ). They reported yield increases of $12 \%$ to $2415 \%$ with SDI compared to rainfed production on a loamy sand. Their report also provides some of the earliest details about installation implements and procedures for SDI, some of which are similar to today's procedures. In a related publication, Mitchell and Tilmon (1982) suggested SDI as a good, economical, alternative irrigation system for small farmers in the U.S. This is because the components of SDI systems can be easily and economically designed to accommodate the field size (Bosch et al., 1992; O'Brien et al., 1998). Several early SDI corn studies (1989 to 1999) from Kansas were discussed by Lamm and Trooien (2003). Major SDI corn research topics have been comparisons of production under SDI and alternative systems; responses to SDI for a particular region, soil, or climate; water and nutrient management; and SDI system design criteria.

\section{System Comparisons for Corn}

A total of twelve studies were found in the literature that allowed equal or nearly equal comparisons of corn grain 
yield under SDI and alternative irrigation systems (table 3). SDI yield increases ranged from $-51 \%$ to $+30 \%$, with an average positive increase of $4 \%$ across all studies. SDI corn grain yields were $7 \%,-16 \%$, and $0 \%$ greater than DI, surface gravity, and sprinkler irrigation, respectively, in these studies. In a study in Egypt, large grain yield declines (23\% to $51 \%$ ) associated with SDI as compared to furrow irrigation and DI were attributed to the reduced ability of SDI to manage salinity in the loamy soil (Abou Kheira, 2009). In contrast, in another study in Egypt (Abuarab et al., 2013), a large yield increase occurred with SDI as compared to DI (23\% and $38 \%$ with and without SDI air injection, respec- tively) in a two-year study on a sandy clay loam. Corn grain yield varied widely with annual weather conditions for SDI and simulated LEPA sprinkler irrigation in a sevenyear study on a deep silt loam soil in Kansas (Lamm, 2004). Although yields on average were similar between the two systems, somewhat surprisingly, yields were approximately $5 \%$ greater with SDI in normal to wetter years and approximately $4 \%$ greater with LEPA sprinkler irrigation in severe drought years (table 1). Greater LEPA yields were associated with more kernels per ear in the drought years (534 kernels per ear with LEPA vs. 493 with SDI), while SDI had greater kernel mass in all years (347 mg per

Table 3. Corn grain yield $\left(\mathrm{Mg} \mathrm{ha}^{-1}\right)$ as affected by irrigation method and average yield increase attributable to SDI.

\begin{tabular}{|c|c|c|c|c|c|c|c|c|}
\hline $\begin{array}{c}\text { Research } \\
\text { Report }\end{array}$ & $\begin{array}{c}\text { Additional Factors } \\
\text { or Comments }\end{array}$ & $\begin{array}{l}\text { Soil } \\
\text { Type }\end{array}$ & $\begin{array}{l}\text { SDI } \\
\text { Dripline } \\
\text { Depth } \\
(\mathrm{m}) \\
\end{array}$ & $\begin{array}{l}\text { Subsurface } \\
\text { Drip } \\
\text { (SDI) } \\
\end{array}$ & $\begin{array}{l}\text { Surface } \\
\text { Drip } \\
\text { (DI) }\end{array}$ & $\begin{array}{l}\text { Surface } \\
\text { Gravity }\end{array}$ & Sprinkler & $\begin{array}{c}\text { Average Increased } \\
\text { Yield using SDI } \\
\text { over Alternative } \\
\text { Methods (\%) }\end{array}$ \\
\hline \multirow{3}{*}{ Abou Kheira, 2009} & $100 \%$ ET & \multirow{3}{*}{ Loamy } & \multirow{3}{*}{0.25} & 7.3 & 7.4 & 11.6 & - & -23 \\
\hline & $80 \%$ ET & & & 4.1 & 7.2 & 9.5 & - & -51 \\
\hline & $60 \%$ ET & & & 3.4 & 4.5 & 8.0 & - & -45 \\
\hline \multirow{2}{*}{ Abuarab et al., 2013} & SDI without air injection & \multirow{2}{*}{$\begin{array}{c}\text { Sandy clay } \\
\text { loam }\end{array}$} & \multirow{2}{*}{0.20} & 11.3 & 9.2 & - & - & 23 \\
\hline & SDI with air injection & & & 12.7 & 9.2 & - & - & 38 \\
\hline \multirow{2}{*}{ Adamsen, 1992} & Nonsodic water & \multirow{2}{*}{$\begin{array}{c}\text { Loamy } \\
\text { sand }\end{array}$} & \multirow{2}{*}{0.41} & 9.9 & - & - & 10.1 & -2 \\
\hline & Sodic water & & & 10.0 & - & - & 9.9 & 1 \\
\hline Camp et al., 1989 & $0.76 \mathrm{~m}$ dripline spacing & $\begin{array}{l}\text { Loamy } \\
\text { sand }\end{array}$ & 0.30 & 11.7 & 12.1 & - & - & -3 \\
\hline \multirow{3}{*}{$\begin{array}{l}\text { Douh and Boujelben, } \\
2011\end{array}$} & $0.05 \mathrm{~m}$ SDI depth & \multirow{3}{*}{$\begin{array}{l}\text { Sandy } \\
\text { clay }\end{array}$} & \multirow{3}{*}{$\begin{array}{c}\text { See } \\
\text { treatment } \\
\text { depth }\end{array}$} & 10.1 & 10.4 & - & - & -3 \\
\hline & $0.20 \mathrm{~m}$ SDI depth & & & 12.4 & 10.4 & - & - & 19 \\
\hline & $0.35 \mathrm{~m}$ SDI depth & & & 13.5 & 10.4 & - & - & 30 \\
\hline \multirow{2}{*}{ Hassanli et al., 2009} & Fresh water & \multirow{2}{*}{ Clay loam } & \multirow{2}{*}{$0.15-0.20$} & 11.8 & 11.4 & 9.6 & - & 9 \\
\hline & Effluent & & & 12.0 & 11.6 & 10.4 & - & 12 \\
\hline \multirow{6}{*}{ Howell et al., 1997} & Daily, $100 \%$ ET & \multirow{6}{*}{ Clay loam } & \multirow{6}{*}{0.30} & 12.9 & 12.8 & - & - & 1 \\
\hline & Weekly, $100 \%$ ET & & & 13.1 & 13.0 & - & - & 0 \\
\hline & Daily, 67\% ET & & & 11.4 & 11.6 & - & - & -2 \\
\hline & Weekly, 67\% ET & & & 11.6 & 10.9 & - & - & 7 \\
\hline & Daily, 33\% ET & & & 6.5 & 6.4 & - & - & 1 \\
\hline & Weekly, 33\% ET & & & 6.6 & 7.0 & - & - & -6 \\
\hline \multirow{9}{*}{ Lamm, 2004} & $\begin{array}{c}\text { All years, } 6.4 \mathrm{~mm} \mathrm{~d}^{-1} \\
\text { irrigation capacity }\end{array}$ & \multirow{9}{*}{ Silt loam } & \multirow{9}{*}{$0.40-0.45$} & 15.5 & - & - & 15.4 & 0 \\
\hline & $\begin{array}{l}\text { All years, } 4.2 \mathrm{~mm} \mathrm{~d}^{-1} \\
\text { irrigation capacity }\end{array}$ & & & 14.7 & - & - & 14.8 & -1 \\
\hline & $\begin{array}{c}\text { All years, } 3.2 \mathrm{~mm} \mathrm{~d}^{-1} \\
\text { irrigation capacity }\end{array}$ & & & 13.7 & - & - & 14.0 & -3 \\
\hline & $\begin{array}{l}\text { Normal years, } 6.4 \mathrm{~mm} \mathrm{~d}^{-1} \\
\text { irrigation capacity }\end{array}$ & & & 17.1 & - & - & 15.7 & 8 \\
\hline & $\begin{array}{l}\text { Normal years, } 4.2 \mathrm{~mm} \mathrm{~d}^{-1} \\
\text { irrigation capacity }\end{array}$ & & & 16.5 & - & - & 15.5 & 6 \\
\hline & $\begin{array}{c}\text { Normal years, } 3.2 \mathrm{~mm} \mathrm{~d}^{-1} \\
\text { irrigation capacity }\end{array}$ & & & 16.0 & - & - & 15.6 & 2 \\
\hline & $\begin{array}{c}\text { Drought years, } 6.4 \mathrm{~mm} \mathrm{~d}^{-1} \\
\text { irrigation capacity }\end{array}$ & & & 14.3 & - & - & 15.2 & -6 \\
\hline & $\begin{array}{c}\text { Drought years, } 4.2 \mathrm{~mm} \mathrm{~d}^{-1} \\
\text { irrigation capacity }\end{array}$ & & & 13.3 & - & - & 14.3 & -7 \\
\hline & $\begin{array}{c}\text { Drought years, } 3.2 \mathrm{~mm} \mathrm{~d}^{-1} \\
\text { irrigation capacity }\end{array}$ & & & 11.9 & - & - & 11.9 & 0 \\
\hline $\begin{array}{l}\text { Mitchell and Sparks, } \\
1982 \\
\end{array}$ & Chiseled treatments & $\begin{array}{c}\text { Loamy } \\
\text { sand }\end{array}$ & 0.36 & 10.6 & 9.1 & - & - & 16 \\
\hline \multirow{2}{*}{ Oron et al., 1991a } & One dripline per bed & \multirow{2}{*}{ Silt loam } & \multirow{2}{*}{0.30} & 10.6 & 10.2 & - & - & 4 \\
\hline & Two driplines per bed & & & 10.1 & 10.0 & - & - & 1 \\
\hline Schultz, 2000 & $\begin{array}{c}\text { Single SDI dripline } \\
\text { shown here }\end{array}$ & Clay loam & $0.15-0.20$ & 9.3 & 9.5 & 8.3 & - & 4 \\
\hline \multirow{6}{*}{ Stone et al., 2008} & $\begin{array}{c}1.0 \mathrm{~m} \text { dripline spacing, } \\
\text { DI and SDI }\end{array}$ & Loamy & & 5.7 & 5.6 & - & - & 2 \\
\hline & $\begin{array}{c}2.0 \mathrm{~m} \text { dripline spacing, } \\
\text { DI and SDI }\end{array}$ & sand & 0.3 & 5.1 & 5.2 & - & - & -2 \\
\hline & & & & Average SD & ncrease a & all studie & $\mathrm{d}$ treatments: & 3 \\
\hline & & & Average SD & increase over & rface gra & rrigation & ss all studies: & -7 \\
\hline & & Ave & SDI increa & over all sprin & er irrigatic & eatments & ss all studies: & 0 \\
\hline & & & & Aver & SDI inc & over DI & ss all studies: & 4 \\
\hline
\end{tabular}


kernel with SDI vs. 332 with LEPA). Although it appears there is little evidence to suggest that SDI greatly increases yields over other well-managed irrigation systems, Lamm (2014) suggested that under deficit irrigation, SDI may stabilize corn yields at a greater level than center-pivot sprinkler irrigation. Water productivity was generally greater for SDI in most of the studies, which might be attributable to less soil water evaporation, less deep percolation, and reduced irrigation and precipitation runoff. SDI can economically compete with less expensive center-pivot sprinkler systems by increasing irrigated land area (i.e., no unirrigated corners, as is often the case with center-pivot sprinklers), particularly when corn selling prices and grain yields are high (O'Brien et al., 1998; Lamm et al., 2015).

\section{SDI Frequency for Corn}

Irrigation frequencies ranging from daily to weekly events have had very little effect on field corn production, provided that soil water was managed within acceptable stress ranges (Caldwell et al., 1994; Camp et al., 1989; Howell et al., 1997). Irrigation water use efficiency was increased $16 \%$ by decreasing the frequency from one to seven days and was attributed to improved storage of precipitation in a deep silt loam soil in the semi-arid region of Kansas (Caldwell et al., 1994). In a later Kansas corn study using a deficit irrigation capacity of $3.8 \mathrm{~mm} \mathrm{~d}^{-1}$, Lamm and Aiken (2005) also found no major effect of SDI frequencies ranging from one to seven days. Irrigation frequency had an effect in only one of the three years of the study; in that extreme drought year, the less-frequent, seven-day treatment had higher grain yield. The number of kernels per ear was greater for the less-frequent irrigation treatments in that drought year. It was hypothesized that the larger irrigation amount (i.e., $26.7 \mathrm{~mm}$ in $7 \mathrm{~d}$ ) for the less-frequent treatment established a larger wetted root zone, allowing for better early-season ear and kernel development. All of these studies were conducted on medium to heavy textured soils, so greater frequency could still be important on lighter textured soils.

\section{Dripline Depth for Corn}

Long-term, multi-year SDI systems are important when growing lesser-value commodity crops such as corn; therefore, deeper dripline depths can be advantageous in avoiding mechanical damage due to tillage and also possibly pest damage (Lamm and Camp, 2007). Dripline depth for SDI corn has been the experimental factor in four research studies found in the literature. Corn grain yields were unaffected by dripline depths ranging from 0.2 to $0.4 \mathrm{~m}$, and there was only a slight yield reduction at 0.5 and $0.6 \mathrm{~m}$ dripline depths on a deep silt loam soil in Kansas (Lamm and Trooien, 2005). The authors concluded that factors external to the study (e.g., producer preferences, tillage schemes, rodent management, need for surface wetting for crop establishment, installation draft requirements, and cost) might have a larger influence on the selection of dripline depth. Dripline depths of $0.15,0.23$, and $0.3 \mathrm{~m}$ were evaluated with two alternative dripline placements (a standard design with driplines spaced at $1.5 \mathrm{~m}$ beneath the crop furrows, and a wider twin-row crop bed design with $1.5 \mathrm{~m}$ dripline spacing) for corn in a study at Bushland, Texas, on a clay loam soil (Colaizzi et al., 2006; Bordovsky et al., 2012b). Although favorable weather conditions negatively affected the determination of dripline depth effects on corn germination and establishment during the three-year period (2006 to 2008), the authors reported that corn grain yields were on average greatest for the standard design when the dripline depth was $0.23 \mathrm{~m}$ and for the wide twin-row crop bed when the dripline depth was $0.30 \mathrm{~m}$. There were no statistically significant differences in dripline depths of $0.25,0.35$, and $0.45 \mathrm{~m}$ for forage corn production on a loamy soil in Mexico (Montemayor Trejo et al., 2006), although the water productivity for all three dripline depths was $45 \%$ greater than for a furrow-irrigated treatment. However, in an SDI corn study on a sandy loam soil in New Mexico, greater plant stands, greater yields, and greater irrigation water use efficiency were reported for 0.15 and $0.2 \mathrm{~m}$ dripline depths than for 0.25 and $0.30 \mathrm{~m}$ depths (Pablo et al., 2007). Plant stands were reported averaging $98 \%$ for the $0.15 \mathrm{~m}$ depth to a dismal $50 \%$ for the $0.3 \mathrm{~m}$ depth in the two-year study, with the authors attributing much of the yield differences to poor crop stands for the deeper depths. Sweet corn yields were $31 \%$ greater for dripline depths of $0.23 \mathrm{~m}$, as compared to $0.33 \mathrm{~m}$ on welldrained sandy soil in Florida (Dukes and Scholberg, 2005). The authors also reported up to $24 \%$ less deep percolation with SDI as compared to sprinkler irrigation. Annual soil water evaporation loss reductions of $23 \%$ and $64 \%$ were predicted for 0.15 and $0.30 \mathrm{~m}$ dripline depths, respectively, compared with DI in a field and modeling study for corn on a Pullman clay loam soil in Texas (Evett et al., 1995), while having no appreciable effect on corn transpiration. Although deeper dripline placement minimizes soil water evaporation losses, this aspect must be balanced with the potential for increased percolation losses, while considering the crop root zone depth and rooting intensity (Gilley and Allred, 1974; Thomas et al., 1974; Philip, 1991).

Deeper SDI driplines can also be beneficial for weed control in field and sweet corn, as reported by Bar-Yosef et al. (1989), Oron et al. (1991b), and Lamm and Trooien (2005). In a study in Israel with a dripline depth of $0.3 \mathrm{~m}$ on a loessial soil, weed growth and the resultant $\mathrm{N}$ uptake by the weeds was reduced by almost $28 \%$ compared with DI for sweet corn production (Bar-Yosef et al., 1989). In the twelve studies listed in table 3 , the average dripline depth was $0.29 \mathrm{~m}$, with depths ranging from 0.15 to $0.45 \mathrm{~m}$. This range of values compares well with the range reported for corn in the SDI review by Camp (1998). In summarizing these dripline depth results for corn, it can be said that both field and sweet corn have extensive root systems that can tap into water applied with deeper driplines (approx. 0.3 to $0.4 \mathrm{~m}$ ), that crop germination may be improved by shallower driplines (approx. 0.2 to $0.25 \mathrm{~m}$ ) in areas where crop establishment is a concern, and that retaining the applied water in the crop root zone is important (i.e., minimizing soil water evaporation and deep percolation) in obtaining the benefits of SDI.

\section{Dripline Spacing for Corn}

Dripline spacing greatly affects SDI system costs, so it should not be surprising that it has been the focus of several 
studies for a lesser-value commodity crop such as corn. As a general rule, SDI dripline spacing is an integer multiple of the crop row spacing, and the crop row or bed spacing is usually set by cultural practices for a given crop in a given region. Dripline spacing for corn is typically an alternate row/bed middle pattern, with one dripline per bed or between two rows, but in a few cases the spacing may be one dripline per row/bed. It appears more dripline spacings studies for corn have been conducted in humid and semihumid regions than in semi-arid and arid regions. This is probably because the annual profitability of irrigation varies more in wetter regions, and researchers are looking for possible practical ways to reduce irrigation investment costs. Grain yield for a $1 \mathrm{~m}$ dripline spacing was $10 \%$ and $28 \%$ greater than for 1.5 and $2.0 \mathrm{~m}$ spacings for corn grown with a $0.9 \mathrm{~m}$ row spacing for a loamy sand in Delaware (Mitchell et al., 1969). However, the $2.0 \mathrm{~m}$ dripline spacing still increased the yield over rainfed production by $18 \%$. Average corn yields were $100 \%, 93 \%$, and $94 \%$ of the maximum yield for dripline spacings of $0.91,1.83$, and $2.74 \mathrm{~m}$ in the humid region of Virginia under adequate irrigation on a loamy sand (Powell and Wright, 1993). In an economic comparison of these results, it was concluded that the $1.8 \mathrm{~m}$ spacing was best for corn and peanut rotations (Bosch et al., 1998) in Virginia and North Carolina. An every-crop row dripline spacing as compared to an alternate row middle placement resulted in greater corn grain yields in $50 \%$ of the years in an eight-year study on a sandy loam soil in Georgia (Sorensen et al., 2013). However, because the narrower dripline spacing only resulted in $4 \%$ greater yields ( 9.2 vs. $\left.8.8 \mathrm{Mg} \mathrm{ha}^{-1}\right)$, the authors concluded that the narrower dripline spacing would probably not be economically justified. Greater row-to-row variability was reported for narrow-row spaced corn $(0.38 \mathrm{~m})$ with wider dripline spacings ( 2 vs. $1 \mathrm{~m}$ ) on a loamy sand in South Carolina, leading the authors to suggest that increasing planting density nearer the driplines might improve productivity (Stone et al., 2008). The $1 \mathrm{~m}$ dripline spacing increased grain yields by $12 \%$ compared to the $2 \mathrm{~m}$ spacing (table 3 ). Similar corn grain yields were reported for 0.76 and $1.52 \mathrm{~m}$ dripline spacings on a clay loam soil in North Carolina (Grabow et al., 2002). Corn grain yields were 13.6, 12.9, 12.3 , and $11.7 \mathrm{Mg} \mathrm{ha}^{-1}$ for dripline spacings of $0.76,1.52$, 2.28 , and $3.04 \mathrm{~m}$, respectively, for $0.76 \mathrm{~m}$ spaced corn rows that were planted perpendicular to the driplines on a silt loam soil in Kansas (Spurgeon et al., 1991). Although yields were greater for the $0.76 \mathrm{~m}$ dripline spacing in this three-year study, the authors concluded that the additional dripline costs would not be justified. However, dripline spacing that is too wide can lead to excessive deep percolation below the crop root zone (Darusman et al., 1997) and large yield reduction or crop failure in rows that are farthest from the dripline (Lamm et al., 1997). Although SDI soil water redistribution is often correlated to some degree with soil texture (i.e., percentages of sand, silt, and clay), wetting can be very different for layered soils of similar texture (Cote et al., 2003; Thorburn et al., 2003). Soil water redistribution models are seldom used for determination of optimal dripline spacing because of the dominance of grower preferences in crop row/bed configurations and their inter- relationship with dripline spacing.

In summarizing the dripline spacing results for corn, it can be said wider dripline spacing may be suitable in soils with layering, allowing increased horizontal soil water redistribution above the soil layer, and in regions that are less dependent on irrigation for crop production, but overall an alternate row/bed dripline spacing (about $1.5 \mathrm{~m}$ ) is usually adequate for corn on medium to heavy textured soils. These results match the conclusions of the review by Camp (1998) and the historical discussion by Camp et al. (2000).

\section{Conjunctive Nutrient and Water Management for Corn}

Fertigation with SDI can be environmentally beneficial as well as potentially improving corn yields through improved plant nutrition and root growth. Some forms of $\mathrm{N}$ are readily leachable, so SDI can be a good tool for timely applications with precise placement in the crop root zone. Combined management of irrigation and anticipated rainfall has long been a necessary tool to manage $\mathrm{N}$ fertilization on sandy soils. SDI with water containing urea-ammonium nitrate (UAN, 32-0-0) can supply both the mobile, but readily absorbed, nitrate- $\mathrm{N}$ and the less mobile ammonium-N, which can be absorbed directly by the plant or microbially transformed to nitrate-N. In a Kansas study on a deep silt loam soil, corn grain yield, plant $\mathrm{N}$ uptake, and water productivity were statistically unaffected by the $\mathrm{N}$ application method (preplant surface application or in-season SDI fertigation), but all three factors were influenced by the combined total $\mathrm{N}$ amount (Lamm et al., 2001). Nearly all of the residual nitrate- $\mathrm{N}$ after corn harvest was within the upper $0.3 \mathrm{~m}$ of the soil profile when all the $\mathrm{N}$ was preplant applied, regardless of the irrigation regime $(75 \%, 100 \%$, and $125 \%$ of $\mathrm{ET}_{\mathrm{c}}$ ). In contrast, under SDI fertigation, nitrate-N concentrations increased with increasing rates of injected $\mathrm{N}$ and migrated deeper into the soil profile with increased irrigation. The results suggest that total $\mathrm{N}$ for corn production potentially could be reduced when using SDI fertigation as compared to surface-applied preplant $\mathrm{N}$ banded in the furrow. In a follow-up study at the same location (Lamm et al., 2004), a best management practice (BMP) for SDI $\mathrm{N}$ fertigation of corn was developed using the criteria of residual ammonium- $\mathrm{N}$ and nitrate- $\mathrm{N}$ levels in the soil profile, grain yield, plant $\mathrm{N}$ uptake, and water productivity. The overall BMP included scheduling irrigation to replace $75 \%$ of the calculated soil water deficit attributable to evapotranspiration, and weekly SDI N fertigations, with the total in-season $\mathrm{N}$ fertigation amount not to exceed $180 \mathrm{~kg} \mathrm{ha}^{-1}$ and the total applied $\mathrm{N}$ not to exceed $210 \mathrm{~kg} \mathrm{ha}^{-1}$. A single early-season $\mathrm{N}$ application was compared to multiple in-season SDI fertigation events on a silt loam soil on Nebraska (Tarkalson and Payero, 2008). Averaged over three years and three total seasonal $\mathrm{N}$ rates $\left(128,186\right.$, or $278 \mathrm{~kg} \mathrm{~N} \mathrm{ha}^{-1}$ ), corn grain yield, plant biomass, and plant $\mathrm{N}$ uptake were $4 \%, 1 \%$, and $10 \%$ greater with the multiple in-season SDI fertigation events. Greater $\mathrm{N}$ use efficiency when using SDI fertigation compared to surface $\mathrm{N}$ applications was also reported for corn production on a silt loam soil in Delaware (Mitchell, 1981), with greater $\mathrm{P}$ and $\mathrm{K}$ availability mentioned as well. Several SDI 
studies (Bar-Yosef et al., 1989; Martinez-Hernandez et al., 1991; Phene et al., 1991; Ben-Gal and Dudley, 2003) examined the effect of $\mathrm{P}$ fertigation on sweet corn production, and their results may suggest that new research for field corn is needed as both irrigation and nutrient management become more intensively managed. Fertigation of $\mathrm{P}$ through SDI increased marketable ear yield by $12 \%$ compared to DI and moved the center of the root density to a deeper depth (i.e., $0.3 \mathrm{~m}$ for SDI and $0.1 \mathrm{~m}$ for DI) on a loessial soil under net/screen house production in Israel (Martinez-Hernandez et al., 1991). Similar results were reported for a field study in California on a clay loam soil for sweet corn P fertigation by Phene et al. (1991), who found that DI had the greatest root density in the 0 to $0.3 \mathrm{~m}$ depth, whereas SDI had greater root density below $0.3 \mathrm{~m}$. Sweet corn yield increases of $4 \%$ to $10 \%$ were reported on a loessial soil in Israel for SDI when compared with DI (Bar-Yosef et al., 1989). Although, total biomass P uptake was unaffected by irrigation system type, the increased ear yield response with SDI was attributed to greater dry matter allocation to the ear. Although $\mathrm{P}$ is considered a relatively immobile nutrient, frequent SDI fertigation can potentially move $\mathrm{P}$ under mass flow to a larger portion of the active corn root zone (Martinez-Hernandez et al., 1991; Ben-Gal and Dudley, 2003).

In summarizing the SDI fertigation studies for corn, it can be said that SDI can be an excellent irrigation system for improved nutrient management. The results emphasize that high-yielding corn production also can be environmentally sound and efficient in both nutrient and water use. However, a caveat is worth mentioning: when water and nutrients are highly managed for greatest effectiveness, there can be less margin of error. It is important that producers are diligent in observing their corn growth and development. Under drought conditions, preplant surfaceapplied $\mathrm{N}$ can become positionally unavailable to the SDI corn because of dry surface layers and insufficient root exploration (Lamm, 2014).

\section{Summary of SDI for Corn}

As corn is by far the major irrigated crop in the U.S., it has garnered considerable SDI research attention even though it is considered a lower-value commodity crop. SDI of corn has generally not increased corn grain yields over well-managed alternative irrigation systems, but SDI may stabilize yields at a greater level when corn is deficit irrigated. Dripline depth for corn often is approximately 0.30 $\mathrm{m}$, and dripline spacing is usually an alternate row middle arrangement. Both of these aspects are important in obtaining cost-effective, multi-year systems that are necessary for SDI adoption for lower-value commodity crops such as corn. Economic competitiveness for SDI as compared to center-pivot sprinklers arises from SDI being able to irrigate a greater fraction of the field area and is improved when corn selling prices and grain yields are higher. As is the case with several other crops, SDI offers opportunities for improved conjunctive management of nutrients and irrigation.

\section{ONION}

Onion (Allium cepa $\mathrm{L}$.) is grown with shallow $(<0.15 \mathrm{~m})$ SDI systems in several areas of the U.S., particularly in the Pacific Northwest states of Oregon and Washington. In many respects, these systems are very similar to DI production, and often the SDI systems are replaced annually for this higher-value crop. The current commercial use of SDI for onions is focused primarily on increasing the fraction of larger onions that can command a premium market price and has a much smaller focus on water conservation (Shock et al., 2013a; Peters, 2015).

\section{System Comparisons for Onion}

Only four studies were found in the literature that allowed equal or nearly equal comparisons of onion yield under SDI and alternative irrigation systems. Increased soil water availability and reduced soil strength on soils wetted by SDI were contributing factors in higher onion yields on a fine sandy loam soil in India (Abrol and Dixit, 1972). The authors found that SDI onion yields were $24 \%$ greater, average diameter was $7 \%$ greater, and irrigation was $7 \%$ less than with the best check-basin surface irrigation method. When compared to check-basin surface irrigation with the same total irrigation amount, SDI onion yield and diameter were $70 \%$ and $25 \%$ greater, respectively. In a study in California on a silty loam soil, no statistical differences in onion yield and water use relationships for SDI and DI were reported (Hanson and May, 2003b). At the highest irrigation level ( $120 \%$ of baseline amount), DI had numerically $7 \%$ greater total yield, $13 \%$ less colossal yield, and $16 \%$ greater jumbo yield than SDI. In comparison, for the driest irrigation treatment, SDI had numerically $10 \%$ greater total yield, $316 \%$ greater colossal yield, and $6 \%$ less jumbo yield. SDI produced $48 \%$ more colossal, $28 \%$ more jumbo, and $32 \%$ fewer medium-sized onions than furrow irrigation in a two-year study on a clay loam soil in Colorado (Halvorson et al., 2008). The authors concluded that SDI could improve the economic returns as well as the irrigation and $\mathrm{N}$ use efficiencies of Colorado onion production systems. On a silt loam soil in eastern Oregon, Feibert et al. (1995) found SDI onion yield to be 5\% and 19\% greater for sprinkler and furrow irrigation, respectively. Since that time, shallow SDI (approx. $0.10 \mathrm{~m}$ depth) for onion has steadily increased in eastern Oregon and was anticipated to reach $50 \%$ of the irrigated onion area by 2013 (Shock et al., 2013a). Extensive research on SDI onion in this region along with grower guidelines were summarized by Shock et al. (2013a, 2013b).

\section{Dripline Depth and Irrigation Management for Onion}

Onion is a shallow-rooted crop, and adequate soil water must be available near the base plate of the bulb for vigorous growth and development. Thus, dripline depth, irrigation onset, and frequency criteria must be carefully considered for SDI onions. Dripline depths of 0, 0.05, 0.10, 0.15, 0.20 , and $0.30 \mathrm{~m}$ were evaluated for onion production on a sandy loam soil in India (Patel and Rajput, 2009). The authors found maximum yield and maximum irrigation water use efficiency for a dripline depth of $0.10 \mathrm{~m}$ across three irrigation levels $(60 \%, 80 \%$, or $100 \% \mathrm{ET})$, although in most 
cases the 0.05 and $0.15 \mathrm{~m}$ depths were statistically similar. Many SDI onion reports indicated dripline depths of 0.05 to $0.10 \mathrm{~m}$ (Feibert et al., 1995; Shock et al., 2005; Halvorson et al., 2008; Shock et al., 2013a, 2013b; Pinto et al., 2014), while a few indicated depths of 0.13 to $0.15 \mathrm{~m}$ (Shock et al., 2000, 2004; Enciso et al., 2009), and a few indicated depths as great as 0.18 to $0.23 \mathrm{~m}$ (Abrol and Dixit, 1972; Bucks et al., 1981; Al-Jamal et al., 2001; Hanson et al., 2003; Hanson and May, 2003b). It appears from these studies that a dripline depth of approximately $0.10 \mathrm{~m}$ is most prevalent. Deeper dripline depths would be advantageous in the harvesting operation and to increase the possibility of multi-year usage, but deeper dripline depths can decrease irrigation efficiency through deep percolation losses (AlJamal et al., 2001) and may not adequately wet the entire onion crop bed in some soil types (Hanson and May, 2003b).

Soil water potentials (SWP) of $-10,-20,-30,-50$, and $70 \mathrm{kPa}$ measured beneath the onion row at the $0.2 \mathrm{~m}$ depth, as controlled by an automated high-frequency irrigation system, were evaluated as SDI management criteria on a silt loam soil in Oregon (Shock et al., 2000). The authors found that total and colossal yields increased with increasing SWP in both years of the study, but that marketable yield tended to be best in the calculated SWP range of -17 to $-21 \mathrm{kPa}$ due to greater onion decomposition in storage. In that report and in later grower recommendations (Shock et al., 2013b), the authors concluded that an SWP management criteria of approximately $-20 \mathrm{kPa}$ is most appropriate for onion production in eastern Oregon on silt loam soils. In a later study (Shock et al., 2005) at the same location, a target SWP of $-20 \mathrm{kPa}$ was compared with varying fixed irrigation event amounts (1.6, 3.2, 6.4, and $13 \mathrm{~mm}$ ), resulting in varying irrigation frequencies (i.e., 564, 269, 121, and 60 events for the 107-day season, respectively). The authors concluded that irrigation event amounts of 6.4 or $13 \mathrm{~mm}$ were superior to the smaller amounts for total, super colossal, and colossal onion yields, and that greater irrigation intensity would result in greater leaching losses.

Marketable onion yields were $15 \%$ greater for daily as compared to weekly irrigation in an Arizona study (Bucks et al., 1981) for a $0.15 \mathrm{~m}$ dripline depth. The authors also reported that they were able to successfully harvest the onion without damaging the SDI system, which would allow multi-season usage. Irrigation scheduled by ET level $(50 \%$, $75 \%$, and $100 \%)$ was compared to SWP level $(-50,-30$, and $-20 \mathrm{kPa}$ ) for SDI onion production in the Lower Rio Grande region of Texas on a sandy clay loam soil (Enciso et al., 2009). The authors found that SWP levels of -20 and $-30 \mathrm{kPa}$ and ET levels of $75 \%$ and $100 \%$ all resulted in statistically similar yields. Numerically, slight increases in total, colossal, and jumbo yields were reported for $-20 \mathrm{kPa}$ SWP and $100 \%$ ET, although these treatments required $12 \%$ more irrigation than the intermediate irrigation levels. Irrigation frequencies of two events per week, one event per day, or two events per day were statistically similar in SDI onion yield and were significantly greater than the yield for weekly irrigation on a sandy loam soil in California (Hanson et al., 2003).

Summarizing these overall onion dripline depth and irri- gation management results, it appears that dripline depth for onion generally is in the range of 0.1 to $0.15 \mathrm{~m}$, and that frequent water applications are necessary (daily or at least twice weekly) to keep SWP near -20 $\mathrm{kPa}$ in the vicinity of the crop row.

\section{Summary of SDI for Onion}

SDI for onion generally provides modest yield improvements over alternative irrigation systems but particularly improves onion quality through increases in the yield fraction of larger onions. Shallow SDI systems are necessary to ensure adequate soil water in the vicinity of the bulb, and the inherent ability of SDI to precisely manage irrigation inputs is advantageous.

\section{Conclusions}

The rationale for using SDI for cotton, processing tomato, corn, and onion production varies. Research results indicate moderate or larger yield increases over alternative irrigation systems for cotton, processing tomato, and onion, with the latter two crops obtaining differences particularly in marketable yield and quality. Yield increases for SDI field corn on average were small or nonexistent compared to other irrigation systems. The rationale for SDI field corn is more related to stabilizing grain yields when the crop is deficit irrigated and to having less non-irrigated land area in quadrilateral fields than with center-pivot sprinkler irrigation. Research indicated that precise water and/or nutrient management was a benefit of SDI for all four crops. Frequency of SDI (daily to weekly) was not important for the deeper-rooted commodity crops (cotton and corn) but tended to be more beneficial for the vegetable crops (tomato and onion). Dripline spacing using an alternate row middle placement was typically acceptable for cotton and corn. Dripline depth for cotton and corn was approximately $0.3 \mathrm{~m}$ and was generally shallower for the vegetable crops, ranging from approximately 0.15 to $0.35 \mathrm{~m}$ for tomato and from 0.10 to $0.15 \mathrm{~m}$ for onion. The use of SDI continues to increase in the U.S. and is currently concentrated in ten states.

\section{REFERENCES}

Abou Kheira, A. A. (2009). Comparison among different irrigation systems for deficit-irrigated corn in the Nile Valley. Agric. Eng. Intl.: CIGR Ejournal, XI, manuscript LW 08010.

Abrol, I. P., \& Dixit, S. P. (1972). Studies of the drip method of irrigation. Exp. Agric., 8(2), 172-175. http://dx.doi.org/10.1017/S0014479700005147.

Abuarab, M., Mostafa, E., \& Ibrahim, M. (2013). Effect of air injection under subsurface drip irrigation on yield and water use efficiency of corn in a sandy clay loam soil. J. Adv. Res., 4(6), 493-499. http://dx.doi.org/10.1016/j.jare.2012.08.009.

Adamsen, F. J. (1992). Irrigation method and water quality effects on corn yield in the mid-Atlantic coastal plain. Agron J., 84(5), 837-843.

http://dx.doi.org/10.2134/agronj1992.00021962008400050015x.

Al-Jamal, M. S., Ball, S., \& Sammis, T. W. (2001). Comparison of sprinkler, trickle, and furrow irrigation efficiencies for onion production. Agric. Water Mgmt., 46(3) 253-266. 
http://dx.doi.org/10.1016/S0378-3774(00)00089-5.

Aloni, N. I., Eizencot, A., Steinberg, Y., Levy, U., Yotal, Y., \& Golan, Z. (2000). Fertigation management and salinity monitoring of cotton cultivated in deep subsurface drip irrigation system. Proc. Natl. Conf. and Exhibition (pp. 153-157). Falls Church, Va.: Irrigation Association.

ASAE. (2007). Standard S526.3: Soil and water terminology. St. Joseph, Mich.: ASAE.

Ayars, J. E., Phene, C. J., Hutmacher, R. B., Davis, K. R., Schoneman, R. A., Vail, S. S., \& Mead, R. M. (1999). Subsurface drip irrigation of row crops: A review of 15 years of research at the Water Management Research Laboratory. Agric. Water Mgmt., 42(1), 1-27. http://dx.doi.org/10.1016/S03783774(99)00025-6.

Bar-Yosef, B., Sagiv, B., \& Markovitch, T. (1989). Sweet corn response to surface and subsurface trickle phosphorous fertigation. Agron. J., 81(3), 443-447.

http://dx.doi.org/10.2134/agronj1989.00021962008100030009x.

Batchelor, C. H., Lovell, C. J., Murata, M., \& McGrath, S. P. (1994). Improving water use effectiveness with subsurface irrigation. Aspects Appl. Biol., 38, 269-278.

Bauer, P. J., Hunt, P. G., \& Camp, C. R. (1997). In-season evaluation of subsurface drip and nitrogen-application method for supplying nitrogen and water to cotton. J. Cotton Sci., 1, 2937.

Ben-Asher, J., \& Silberbush, M. (1992). Root distribution under trickle irrigation: Factors affecting distribution and comparison among methods of determination. J. Plant Nutrition, 15(6-7), 783-794.

Ben-Gal, A., \& Dudley, L. M. (2003). Phosphorus availability under continuous point-source irrigation. SSSA J., 67(5), 14491456. http://dx.doi.org/10.2136/sssaj2003.1449.

Bhattarai, S. P., Huber, S., \& Midmore, D. J. (2004). Aerated subsurface irrigation gives growth and yield benefits to zucchini, vegetable soybean, and cotton in heavy clay soils. Ann. Appl. Biol., 144(3), 285-298. http://dx.doi.org/10.1111/j.17447348.2004.tb00344.x.

Bhattarai, S. P., McHugh, A. D., Lotz, G., \& Midmore, D. J. (2005). The response of cotton to subsurface drip and furrow irrigation in a vertisol. Exp. Agric., 42(1), 29-49. http://dx.doi.org/10.1017/S0014479705003029.

Bogle, C. R., Hartz, T. K., \& Nunez, C. (1989). Comparison of subsurface trickle and furrow irrigation on plastic-mulched and bare soil for tomato production. J. American Hort. Sci., 114(1), 40-43.

Bordovsky, J. P., \& Lyle, W. M. (1998). Cotton irrigation with LEPA and subsurface drip systems on the Southern High Plains. Proc. Beltwide Cotton Conf. (pp. 409-412). Cordova, Tenn.: National Cotton Council.

Bordovsky, J. P., \& Porter, D. (2003). Cotton response to pre-plant irrigation level and irrigation capacity using spray, LEPA and subsurface drip irrigation. ASAE Paper No. 032008. St. Joseph, Mich.: ASAE.

Bordovsky, J. P., Emerson, C. L., \& Mustian, J. T. (2012a). Irrigation interval effects on cotton production using subsurface drip systems. ASABE Paper No. 121337401. St. Joseph, Mich.: ASABE.

Bordovsky, J. P., Cranmer, A. M., Colaizzi, P. D., Lamm, F. R., Evett, S. R., \& Howell, T. A. (2012b). Investigating strategies to improve crop germination when using SDI. In Proc. 24th Ann. Central Plains Irrig. Conf. Colby, Kans.: Central Plains Irrigation Association.

Bosch, D. J., Powell, N. L., \& Wright, F. S. (1992). An economic comparison of subsurface microirrigation and center-pivot sprinkler irrigation. J. Prod. Agric., 5(4), 431-437. http://dx.doi.org/10.2134/jpa1992.0431.
Bosch, D. J., Powell, N. L., \& Wright, F. S. (1998). Investment returns from three subsurface microirrigation tubing spacings. $J$. Prod. Agric., 11(3), 371-376.

http://dx.doi.org/10.2134/jpa1998.0371.

Bucks, D. A., Erie, L. J., French, O. F., Nakayama, F. S., \& Pew, W. D. (1981). Subsurface trickle irrigation management with multiple cropping. Trans. ASAE, 24(6), 1482-1489. http://dx.doi.org/10.13031/2013.34478.

Caldwell, D. S., Spurgeon, W. E., \& Manges, H. L. (1994). Frequency of irrigation for subsurface drip-irrigated corn. Trans. ASAE, 37(4), 1099-1103.

http://dx.doi.org/10.13031/2013.28181.

Camp, C. R. (1998). Subsurface drip irrigation: A review. Trans. ASAE, 41(5), 1353-1367. http://dx.doi.org/10.13031/2013.17309.

Camp, C. R., Sadler, E. J., \& Busscher, W. J. (1989). Subsurface and alternate-middle micro irrigation for the southeast coastal plain. Trans. ASAE, 32(2), 451-456. http://dx.doi.org/10.13031/2013.31025.

Camp, C. R., Bauer, P. J., \& Hunt, P. G. (1997). Subsurface drip irrigation lateral spacing and management for cotton in the southeastern coastal plain. Trans. ASAE, 40(4), 993-999. http://dx.doi.org/10.13031/2013.21351.

Camp, C. R., Lamm, F. R., Evans, R. G., \& Phene, C. J. (2000). Subsurface drip irrigation: Past, present, and future. In Proc. 4th Decennial Natl. Irrig. Symp. (pp. 363-372). St. Joseph, Mich.: ASAE.

Clark, G. A., Stanley, C. D., \& Maynard, D. N. (1993). Surface vs. subsurface drip irrigation of tomatoes on a sandy soil. Proc. Florida State Hort. Soc., 106, 210-212.

Colaizzi, P. D., Evett, S. R., \& Howell, T. A. (2006). Crop emergence with alternative SDI designs in a Pullman clay loam soil. In Proc. 28th Annual Southern Conservation Systems Conf. (pp. 16-24). Bushland, Tex.: USDA-ARS Conservation and Production Research Laboratory.

Colaizzi, P. D., Evett, S. R., Howell, T. A., \& Baumhardt, R. L. (2010). Crop production comparison with spray, LEPA, and subsurface drip irrigation in the Texas High Plains. In Proc. Fifth Natl. Irrig. Symp. St. Joseph, Mich.: ASABE.

Constable, G. A., \& Hodgson, A. S. (1990). A comparison of drip and furrow irrigated cotton on a cracking clay soil: 3 . Yield and quality of four cultivars. Irrig. Sci., 11(3), 149-153. http://dx.doi.org/10.1007/BF00189450.

Constable, G. A., Rochester, I. J., \& Hodgson, A. S. (1990). A comparison of drip and furrow irrigated cotton on clay soil: 1 . Growth and nitrogen uptake. Irrig. Sci., 11(3), 137-142. http://dx.doi.org/10.1007/BF00189450.

Cote, C. M., Bristow, K. L., Charlesworth, P. B., Cook, F. J., \& Thorburn, P. J. (2003). Analysis of soil wetting and solute transport in subsurface trickle irrigation. Irrig. Sci., 22(3), 143156. http://dx.doi.org/10.1007/s00271-003-0080-8.

Darusman, Khan, A. H., Stone, L. R., \& Lamm, F. R. (1997). Water flux below the root zone vs. drip-line spacing in drip irrigated corn. SSSA J., 61(6), 1755-1760.

del Amor, M. A., \& del Amor, F. M. (2007). Response of tomato plants to deficit irrigation under surface or subsurface drip irrigation. J. Appl. Hort., 97(2), 97-100.

Devasirvatham, V. (2009). A review of subsurface drip irrigation in vegetable production. Irrigation Matters Series No. 03/09. Darling Heights, Queensland, Australia: Cooperative Research Centre for Irrigation Futures. Retrieved from www.irrigationfutures.org.au/imagesdb/news/crcif-im0309web.pdf.

Douh, B., \& Boujelben, A. (2011). Effects of surface and subsurface drip irrigation on agronomic parameters of maize (Zea mays L.) under Tunisian climatic condition. J. Natl. Prod. 
Plant Resour., 1(3), 8-14.

Dukes, M. D., \& Scholberg, J. M. (2005). Soil moisture controlled subsurface drip irrigation on sandy soils. Appl. Eng. Agric., 21(1), 89-101. http://dx.doi.org/10.13031/2013.17916.

El-Gindy, A. M., \& El-Araby, A. M. (1996). Vegetable crop response to surface and subsurface drip under calcareous soil. Proc. Intl. Conf. Evapotranspiration and Irrig. Scheduling (pp. 1021-1028). St. Joseph, Mich.: ASAE.

Enciso, J. M., Colaizzi, P. D., \& Multer, W. L. (2005). Economic analysis of subsurface drip irrigation lateral spacing and installation depth for cotton. Trans. ASAE, 48(1), 197-204. http://dx.doi.org/10.13031/2013.17963.

Enciso, J., Wiedenfeld, B., Jifon, J., \& Nelson, S. (2009). Onion yield and quality response to two irrigation scheduling strategies. Scientia Hort., 120(3), 301-305. http://dx.doi.org/10.1016/j.scienta.2008.11.004.

Enciso-Medina, J., Unruh, B. L., Colaizzi, P. D., \& Multer, W. L. (2003). Cotton response to subsurface drip irrigation frequency under deficit irrigation. Appl. Eng. Agric., 19(5), 555-558.

Evett, S. R., Howell, T. A., \& Schneider, A. D. (1995). Energy and water balances for surface and subsurface drip irrigated corn. In F. R. Lamm (Ed.), Proc. 5th Intl. Microirrig. Congress (pp. 135140). St. Joseph, Mich.: ASAE.

Feibert, E. B. G., Shock, C. C., \& Saunders, L. D. (1995). A comparison of sprinkler, subsurface drip, and furrow irrigation of onions. Special Report 947. Corvallis, Ore.: Oregon State University Agricultural Experiment Station.

Gilley, J. R., \& Allred, E. R. (1974). Infiltration and root extraction from subsurface irrigation laterals. Trans. ASAE, 17(5), 927-933. http://dx.doi.org/10.13031/2013.37000.

Grabow, G. L., Huffman, R. L., Evans, R. O., Edmisten, K. L., \& Jordan, D. L. (2002). Subsurface drip irrigation research on commodity crops in North Carolina. ASAE Paper No. 022290. St. Joseph, Mich.: ASAE.

Grattan, S. R., Schwankl, L. J., \& Lanini, W. T. (1990). Distribution of annual weeds in relation to irrigation method. In Proc. 3rd Natl. Irrig. Symp. (pp. 148-153). ASAE: St. Joseph, Mich.

Halvorson, A. D., Bartolo, M. E., Reule, C. A., \& Berrada, A. (2008). Nitrogen effects on onion yield under drip and furrow irrigation. Agron. J., 100(4), 1062-1069. http://dx.doi.org/10.2134/agronj2007.0377.

Hanson, B. R., \& May, D. M. (2000). Response of processing tomato yield to drip irrigation under saline, shallow groundwater conditions. In Proc. 4th Natl. Irrig. Symp. (pp. 385-390). St. Joseph, Mich.: ASAE.

Hanson, B., \& May, D. M. (2003a). Effect of subsurface drip irrigation on processing tomatoes yield, water table depth, and soil salinity ASAE Paper No. 032091. St. Joseph, Mich.: ASAE.

Hanson, B., \& May, D. M. (2003b). Response of processing and fresh-market onions to drip irrigation. ASAE Paper No. 032094. St. Joseph, Mich.: ASAE.

Hanson, B., \& May, D. M. (2007). The effect of dripline placement on yield and quality of drip-irrigated processing tomatoes. Irrig. Drain. Syst., 21(2), 109-118. http://dx.doi.org/10.1007/s10795007-9023-5.

Hanson, B. R., May, D. M., \& Schwankl, L. J. (2003). Effect of irrigation frequency on subsurface drip irrigated vegetables. HortTech., 13(1), 115-120.

Hanson, E. G., Williams, B. C., Fangmeier, D. D., \& Wilke, O. C. (1970). Influence of subsurface irrigation on crop yields and water use. In Proc. Natl. Irrig. Symp. (pp. D1-D13). St. Joseph, Mich.: ASAE.

Hassanli, A. M., Ebrahimizadeh, M. A., \& Beecham, S. (2009). The effects of irrigation methods with effluent and irrigation scheduling on water use efficiency and corn yields in an arid region. Agric. Water Mgmt., 96(1), 93-99. http://dx.doi.org/10.1016/j.agwat.2008.07.004.

Hollingsworth, J., Mitchell, J. P., Munk, D. S., Roberts, B. A., \& Shresetha, A. (2014). Subsurface drip and overhead irrigation effects on conservation-tilled cotton in the San Joaquin Valley. J. Crop Improvement, 28(3), 324-344.

http://dx.doi.org/10.1080/15427528.2014.881449.

House, E. B. (1918). Irrigation by means of underground porous pipe. Bulletin 240. Fort Collins, Colo.: Colorado Agricultural Experiment Station.

Howell, T. A., Schneider, A. D., \& Evett, S. R. (1997). Subsurface and surface microirrigation of corn, Southern High Plains. Trans. ASAE, 40(3), 635-641. http://dx.doi.org/10.13031/2013.21322.

HPWD. (2014). High Plains Water District 2013 subsurface drip irrigation locations. Lubbock, Tex.: High Plains Water District. Retrieved from www.hpwd.org/s/SDI_2013.pdf.

Hulme, P., \& O’Brien, B. (2000). Managing subsurface drip irrigation in hardsetting red soil: Implications of small wetted area. In Proc. Natl. Conf. and Exhibition (pp. 385-390). Hornsby, NSW, Australia: Irrigation Association of Australia.

Kahlaoui, B., Hachicha, M., Rejeb, S., Rejeb, M. N., Hanchi, B., \& Misle, E. (2011). Effects of saline water on tomato under subsurface drip irrigation: Nutritional and foliar aspects. J. Soil Sci. Plant Nutr., 11(1), 69-86. http://dx.doi.org/10.4067/S071895162011000100007.

Kamara, L., Zartman, R., \& Ramsey, R. H. (1991). Cotton-root distribution as a function of trickle emitter depth. Irrig. Sci., 12(3), 141-144. http://dx.doi.org/10.1007/BF00192285.

Khalilian, A., Sullivan, M. J., \& Smith, W. B. (2000). Lateral depth placement and deep tillage effects in a subsurface drip irrigation system for cotton. In Proc. 4th Natl. Irrig. Symp. (pp. 641-646). St. Joseph, Mich.: ASAE.

Lamm, F. R. (2004). Comparison of SDI and simulated LEPA sprinkler irrigation for corn. In Proc. Intl. Irrig. Tech. Conf. (pp. 475-485). IA Paper No. IA04-1098. Falls Church, Va.: Irrigation Association.

Lamm, F. R. (2014). Irrigation and nitrogen management for subsurface drip irrigated corn: 25 years of K-State's efforts. ASABE Paper No. 141914980. St. Joseph, Mich.: ASABE.

Lamm, F. R., \& Aiken, R. M. (2005). Effect of irrigation frequency for limited subsurface drip irrigation of corn. In Proc. Intl. Tech. Conf. IA Paper No. IA05-1264. Falls Church, Va.: Irrigation Association.

Lamm, F. R., \& Camp, C. R. (2007). Subsurface drip irrigation. In F. R. Lamm, J. E. Ayars, \& F. S. Nakayama (Eds.), Microirrigation for Crop Production: Design, Operation, and Management (pp. 473-551). Amsterdam, The Netherlands: Elsevier. http://dx.doi.org/10.1016/S0167-4137(07)80016-3.

Lamm, F. R., \& Trooien, T. P. (2003). Subsurface drip irrigation for corn production: A review of 10 years of research in Kansas. Irrig. Sci., 22(3-4), 195-200.

Lamm, F. R., \& Trooien, T. P. (2005). Dripline depth effects on corn production when crop establishment is nonlimiting. Appl. Eng. Agric., 21(5), 835-840. http://dx.doi.org/10.13031/2013.19710.

Lamm, F. R., Stone, L. R., Manges, H. L., \& O’Brien, D. M. (1997). Optimum lateral spacing for subsurface drip-irrigated corn. Trans. ASAE, 40(4), 1021-1027. http://dx.doi.org/10.13031/2013.21354.

Lamm, F. R., Trooien, T. P., Manges, H. L., \& Sunderman, H. D. (2001). Nitrogen fertilization for subsurface drip-irrigated corn. Trans. ASAE, 44(3), 533-542. http://dx.doi.org/10.13031/2013.6113.

Lamm, F. R., Schlegel, A. J., \& Clark, G. A. (2004). Development of a best management practice for nitrogen fertigation of corn using SDI. Appl. Eng. Agric., 20(2), 211-220. 
http://dx.doi.org/10.13031/2013.15894.

Lamm, F. R., Colaizzi, P. D., Bordovsky, J. P., Trooien, T. P., Enciso-Medina, J., Porter, D. O., Rogers, D. H., \& O’Brien, D. M. (2010). Can subsurface drip irrigation (SDI) be a competitive irrigation system in the Great Plains region for commodity crops? In Proc. 5th Natl. Decennial Irrig. Conf. St. Joseph, Mich.: ASABE.

Lamm, F. R., Bordovsky, J. P., Schwankl, L. J., Grabow, G. L., Enciso-Medina, J., Peters, R. T., Colaizzi, P. D., Trooien, T. P., $\&$ Porter, D. O. (2012). Subsurface drip irrigation: Status of the technology in 2010. Trans. ASABE, 55(2), 483-491. http://dx.doi.org/10.13031/2013.41387.

Lamm, F. R., O’Brien, D. M., \& Rogers, D. H. (2015). Using the KState center-pivot sprinkler and SDI economic comparison spreadsheet-2015. In Proc. 27th Ann. Central Plains Irrig. Conf. (pp. 108-116). Colby, Kans.: Central Plains Irrigation Association.

Machado, R. M. A., do Rosario, M., Oliveira, G., \& Portas, C. A. (2003). Tomato root distribution, yield, and fruit quality under subsurface drip irrigation. Plant Soil, 255(1), 333-341. http://dx.doi.org/10.1023/A:1026191326168.

Machado, R. M. A., do Rosario, M., \& Oliveira, G. (2005). Tomato root distribution, yield, and fruit quality under different subsurface drip irrigation regimes and depths. Irrig. Sci., 24(1), 15-24. http://dx.doi.org/10.1007/s00271-005-0002-z.

Marouelli, W. A., \& Silva, W. L. C. (2002). Profundidade de instalacao da linha de gotejadores em tomateiro para processamento industrial. Horticultura Brasileira, 20(2), 206210. http://dx.doi.org/10.1590/S0102-05362002000200018.

Martinez-Hernandez, J. J., Bar-Yosef, B., \& Kafkafi, U. (1991). Effect of surface and subsurface drip fertigation on sweet corn rooting, uptake, dry matter production, and yield. Irrig. Sci., 12(3), 153-159. http://dx.doi.org/10.1007/BF00192287.

Mitchell, W. H. (1981). Subsurface irrigation and fertilization for corn. Agron. J., 73(6), 913-916. http://dx.doi.org/10.2134/agronj1981.00021962007300060002x.

Mitchell, W. H., \& Sparks, D. L. (1982). Influence of subsurface irrigation and organic additions on top and root growth of field corn. Agron. J., 74(6), 1084-1088. http://dx.doi.org/10.2134/agronj1982.00021962007400060037x.

Mitchell, W. H., \& Tilmon, H. D. (1982). Underground trickle irrigation: The best system for small farms? Crops Soils, 34(5), 9-13.

Mitchell, W. H., McVaine, J. E., \& Mueller, J. P. (1969). Subsurface irrigation with perforated plastic tubing. Bulletin 99. Agricultural Extension Service.

Montazar, A. (2015). Personal communication from agricultural water management specialist, Department of Plant Sciences, University of California-Davis. January 7, 2015.

Montemayor Trejo, J. A., Gómez Monsivais, A. O., Olague Ramírez, J., Zermeno González, A., Ruiz Cerda, E., Fortis Hernández, M., Salazar Sosa, E., \& Aldaco Nuncia, R. (2006). Effect of three driptape installation depths on water use efficiency and yield parameters in forage maize. Técnica Pecuaria en México, 44(3), 359-364.

Najafi, P., \& Tabatabaei, S. H. (2007). Effect of using subsurface drip irrigation and ET-HS model to increase WUE in irrigation of some crops. Irrig. Drain., 56(4), 477-486. http://dx.doi.org/10.1002/ird.322.

Nuti, R. C., Casteel, S. N., Viator, R. P., Lanier, J. E., Edmisten, K. L., Jordan, D. L., Grabow, G. L., Barnes, J. S. Mathews, J. W., $\&$ Wells, R. (2006). Management of cotton grown under overhead sprinkle and subsurface drip irrigation. J. Cotton Sci., 10(2), 76-88.

O’Brien, D. M., Rogers, D. H., Lamm, F. R., \& Clark, G. A. (1998).
An economic comparison of subsurface drip and center-pivot sprinkler irrigation systems. Appl. Eng. Agric., 14(4), 391-398. http://dx.doi.org/10.13031/2013.19401.

Oron, G., DeMalach, Y., Hoffman, Z., \& Cibotaru, R. (1991a). Subsurface microirrigation with effluent. ASCE J. Irrig. Drain. Eng., 117(1), 25-36. http://dx.doi.org/10.1061/(ASCE)07339437(1991)117:1(25).

Oron, G., DeMalach, Y., Hoffman, Z., Keren, Y., Hartman, H., \& Plazner, N. (1991b). Wastewater disposal by subsurface trickle irrigation. Water Sci. Tech., 23(10-12), 2149-2158.

Pablo, R. G., O’Neill, M. K., McCastin, B. D., Remmenga, M. D., Keenan, J. G., \& Onken, B. M. (2007). Evaluation of corn grain yield and water use efficiency using subsurface drip irrigation. $J$. Sustain. Agric., 30(1), 153-172. http://dx.doi.org/10.1300/J064v30n01_10.

Patel, N., \& Rajput, T. B. (2009). Effect of subsurface drip irrigation on onion yield. Irrig. Sci., 27(2), 97-108. http://dx.doi.org/10.1007/s00271-008-0125-0.

Peters, R. T. (2015). Personal communication from agricultural water management specialist, Washington State University. January 5, 2015.

Phene, C. J., Davis, K. R., Hutmacher, R. B., \& McCormick, R. L. (1987). Advantages of subsurface irrigation for processing tomatoes. Acta Hort., 200, 101-114.

Phene, C. J., Hutmacher, R. B., Davis, K. R., \& McCormick, R. L. (1990). Water-fertilizer management of processing tomatoes. Acta Hort., 277, 137-143.

Phene, C. J., Davis, K. R., Hutmacher, R. B., Bar-Yosef, B., Meek, D. W., \& Misaki, J. (1991). Effect of high-frequency surface and subsurface drip irrigation on root distribution of sweet corn. Irrig. Sci., 12(3), 135-140. http://dx.doi.org/10.1007/BF00192284.

Phene, C. J., DeTar, W. R., \& Clark, D. A. (1992). Real-time irrigation scheduling of cotton with an automated pan evaporation system. Appl. Eng. Agric., 8(6), 787-793. http://dx.doi.org/10.13031/2013.26114.

Philip, J. R. (1991). Effects of root and subirrigation depth on evaporation and percolation losses. SSSA J., 55(6), 1520-1523. http://dx.doi.org/10.2136/sssaj1991.03615995005500060003x.

Pinto, J. M., Shock, C. C., \& Feibert, E. B. G. (2014). Optimal practices for drip irrigated onion differ based on growers' market opportunities. In Proc. 2014 Irrig. Assoc. Tech. Conf. Falls Church, Va.: Irrigation Association.

Plaut, Z., Carmi, A., \& Grava, A. (1996). Cotton root and shoot responses to subsurface drip irrigation and partial wetting of the upper soil profile. Irrig. Sci., 16(3), 107-113. http://dx.doi.org/10.1007/BF02215618.

Plaut, Z., Rom, M., \& Meiri, A. (1985). Cotton response to subsurface trickle irrigation. In Proc. 3rd Intl. Drip Trickle Irrig. Congress (vol. 2, pp. 887-895). St. Joseph, Mich.: ASAE.

Powell, N. L., \& Wright, F. S. (1993). Grain yield of subsurface microirrigated corn as affected by irrigation line spacing. Agron. J., 85(6), 1165-1170. http://dx.doi.org/10.2134/agronj1993.00021962008500060014x.

Rodríguez-Sinobas, L., \& Gil-Rodríguez, M. (2012). Chapter 10: A review of subsurface drip irrigation and its management. In T. S. Lee (Ed.), Water Quality, Soil, and Managing Irrigation of Crops (pp. 171-194). Rijeka, Croatia: InTech. Retrieved from www.intechopen.com/books/water-quality-soil-andmanagingirrigation-of-crops/a-review-of-subsurface-dripirrigation-and-its-management.

Schulz, M. (2000). Microirrigation of maize. In Proc. Natl. Conf. and Exhibition (pp. 398-405). Hornsby, NSW, Australia: Irrigation Association of Australia.

Schwankl, L. J., Grattan, S. R., \& Miyao, E. M. (1990). Drip irrigation burial depth and seed planting depth effects on tomato 
germination. In Proc. 3rd Natl. Irrig. Symp. (pp. 682-687). St. Joseph, Mich.: ASAE.

Shock, C. C., Feibert, E. B. G., \& Saunders, L. D. (2000). Irrigation criteria for drip-irrigated onions. HortSci., 35(1), 63-66.

Shock, C. C., Feibert, E. B. G., \& Saunders, L. D. (2004). Plant population and nitrogen fertilization for subsurface drip-irrigated onion. HortSci., 39(7), 1722-1727.

Shock, C. C., Feibert, E. B. G., \& Saunders, L. D. (2005). Onion response to drip irrigation intensity and emitter flow rate. HortTech., 15(3), 652-659.

Shock, C. C., Feibert, E. B. G., \& Pinto, J. M. (2013a). Review of two decades of progress in the development of successful drip irrigation for onions. In Proc. 2013 Irrig. Assoc. Tech. Conf. Falls Church, Va.: Irrigation Association.

Shock, C. C., Flock, R., Feibert, E., Shock, C. A., \& Klauzer, J. (2013b). Drip irrigation guide for onion growers. Publication EM 8901. Corvallis, Ore.: Oregon State University Extension.

Shrestha, A., Mitchell, J. P., \& Lanini, W. T. (2007). Subsurface drip irrigation as a weed management tool for conventional and conservation tillage tomato (Lycopersicon esculentum Mill.) production in semi-arid agroecosystems. J. Sustain. Agric., 31(2), 91-112. http://dx.doi.org/10.1300/J064v31n02_07.

Smith, R. B., Oster, J. D., \& Phene, C. J. (1991). Subsurface drip produced highest net return in Westlands area study. California Agric., 45(2), 8-11.

Sorensen, R. B., Bader, M. J., \& Wilson, E. H. (2004). Cotton yield and grade response to nitrogen applied daily through a subsurface drip irrigation system. Appl. Eng. Agric., 20(1), 1316. http://dx.doi.org/10.13031/2013.15689.

Sorensen, R. B., Butts, C. L., \& Nuti, R. C. (2011). Deep subsurface drip irrigation for cotton in the southeast. J. Cotton Sci., 15(3), 233-242.

Sorensen, R. B., Butts, C. L., \& Lamb, M. C. (2013). Corn yield response to deep subsurface drip irrigation in the southeast. Crop Mgmt., 12(1), doi: 10.1094/CM-2013-0122-01-RS.

Spurgeon, W. E., Manges, H. L., \& Makens, T. P. (1991). Drip line spacing and plant population for corn. ASAE Paper No. 912592. St. Joseph, Mich.: ASAE.

Stone, K. C., Bauer, P. J., Busscher, W. J., \& Millen, J. A. (2008). Narrow row corn production with subsurface drip irrigation. Appl. Eng. Agric., 24(4), 455-464. http://dx.doi.org/10.13031/2013.25146.

Tan, C. S., Zhang, T. Q., Reynolds, W. D., Drury, C. F., \& Liptay, A. (2003). Farm-scale processing tomato production using surface and subsurface drip irrigation and fertigation. ASAE Paper No. 032092. St. Joseph, Mich.: ASAE.

Tarkalson, D. D., \& Payero, J. O. (2008). Comparison of nitrogen fertilization methods and rates for subsurface drip irrigated corn in the semi-arid Great Plains. Trans. ASABE, 51(5), 1633-1643. http://dx.doi.org/10.13031/2013.25320.

Taylor, R., Parker, D., \& Zilberman, D. (2014). Contribution of University of California Cooperative Extension to drip irrigation. ARE Update, 18(2), 5-8. Davis, Cal.: University of California, Giannini Foundation of Agricultural Econnmics. Retrieved from http://giannini.ucop.edu/media/areupdate/files/articles/V18N2_2.pdf.

Thomas, A. W., Kruse, E. G., \& Duke, H. R. (1974). Steady infiltration from line sources buried in the soil. Trans. ASAE, 17(1), 125-133. http://dx.doi.org/10.13031/2013.36803.

Thompson, W. J., \& Enciso, J. M. (2002). Why subsurface drip irrigation (SDI)? An economic analysis. In Proc. Beltwide Cotton Conf. Cordova, Tenn.: National Cotton Council.

Thorburn, P. J., Cook, F. J., \& Bristow, K. L. (2003). Soildependent wetting from trickle emitters: Implications for system design and management. Irrig. Sci., 22(3), 121-127. http://dx.doi.org/10.1007/s00271-003-0077-3.

Tollefson, S. (1985). Subsurface drip irrigation of cotton and small grains. In Proc. 3rd Intl. Drip Trickle Irrig. Congress (vol. 2, pp. 887-895). St. Joseph, Mich.: ASAE.

USDA-NASS. (2004). Farm and ranch irrigation survey (2003). 2002 Census of Agriculture, Vol. 3, Special Studies, Part 1 (AC02-SS-1). Washington, D.C.: USDA National Agricultural Statistics Service.

USDA-NASS. (2010). Farm and ranch irrigation survey (2008). 2007 Census of Agriculture, Vol. 3, Special Studies, Part 1 (AC07-SS-1). Washington, D.C.: USDA National Agricultural Statistics Service.

USDA-NASS. (2014). Farm and ranch irrigation survey (2013). 2012 Census of Agriculture, Vol. 3, Special Studies, Part 1 (AC12-SS-1). Washington, D.C.: USDA National Agricultural Statistics Service.

Whitaker, J. R., Ritchie, G. L., Bednarz, C. W., \& Mills, C. I. (2008). Cotton subsurface drip and overhead irrigation efficiency, maturity, yield, and quality. Agron. J., 100(6), 17631768. http://dx.doi.org/10.2134/agronj2008.0036.

Zetzsche, J. B., \& Newman, J. S. (1966). Subirrigation with plastic pipe. Agric. Eng., 47(1), 74-75. 